\title{
Vitamin D: a critical and essential micronutrient for human health
}

\author{
Igor Bendik*, Angelika Friedel, Franz F. Roos, Peter Weber and Manfred Eggersdorfer \\ Human Nutrition and Health (IB, AF, FFR), and Nutrition Science \& Advocacy (PW, ME), DSM Nutritional Products Ltd., Basel, Switzerland
}

\section{Edited by:}

Carsten Carlberg, University of

Eastern Finland, Finland

Reviewed by:

Katie Marie Dixon, The University of

Sydney, Australia

Miguel A. Maestro, University of

A Coruña, Spain

*Correspondence:

Igor Bendik, Department of Human

Nutrition and Health, DSM

Nutritional Products Ltd., Bldg.

201/219A, PO Box 2676, CH-4002

Kaiseraugst, Basel, Switzerland

e-mail: igor.bendik@dsm.com
Vitamin $D$ is a micronutrient that is needed for optimal health throughout the whole life. Vitamin $\mathrm{D}_{3}$ (cholecalciferol) can be either synthesized in the human skin upon exposure to the UV light of the sun, or it is obtained from the diet. If the photoconversion in the skin due to reduced sun exposure (e.g., in wintertime) is insufficient, intake of adequate vitamin $D$ from the diet is essential to health. Severe vitamin D deficiency can lead to a multitude of avoidable illnesses; among them are well-known bone diseases like osteoporosis, a number of autoimmune diseases, many different cancers, and some cardiovascular diseases like hypertension are being discussed. Vitamin D is found naturally in only very few foods. Foods containing vitamin D include some fatty fish, fish liver oils, and eggs from hens that have been fed vitamin $D$ and some fortified foods in countries with respective regulations. Based on geographic location or food availability adequate vitamin $D$ intake might not be sufficient on a global scale. The International Osteoporosis Foundation (IOF) has collected the 25-hydroxy-vitamin D plasma levels in populations of different countries using published data and developed a global vitamin D map. This map illustrates the parts of the world, where vitamin $\mathrm{D}$ did not reach adequate 25 -hydroxyvitamin $\mathrm{D}$ plasma levels: $6.7 \%$ of the papers report 25 -hydroxyvitamin $D$ plasma levels below $25 \mathrm{nmol} / \mathrm{L}$, which indicates vitamin D deficiency, $37.3 \%$ are below $50 \mathrm{nmol} /$ Land only $11.9 \%$ found 25-hydroxyvitamin D plasma levels above $75 \mathrm{nmol} / \mathrm{L}$ target as suggested by vitamin $D$ experts. The vitamin $D$ map is adding further evidence to the vitamin $D$ insufficiency pandemic debate, which is also an issue in the developed world. Besides malnutrition, a condition where the diet does not match to provide the adequate levels of nutrients including micronutrients for growth and maintenance, we obviously have a situation where enough nutrients were consumed, but lacked to reach sufficient vitamin $D$ micronutrient levels. The latter situation is known as hidden hunger. The inadequate vitamin $D$ status impacts on health care costs, which in turn could result in significant savings, if corrected. Since little is known about the effects on the molecular level that accompany the pandemic like epigenetic imprinting, the insufficiency-triggered gene regulations or the genetic background influence on the body to maintain metabolic resilience, future research will be needed. The nutrition community is highly interested in the molecular mechanism that underlies the vitamin D insufficiency caused effect. In recent years, novel large scale technologies have become available that allow the simultaneous acquisition of transcriptome, epigenome, proteome, or metabolome data in cells of organs. These important methods are now used for nutritional approaches summarized in emerging scientific fields of nutrigenomics, nutrigenetics, or nutriepigenetics. It is believed that with the help of these novel concepts further understanding can be generated to develop future sustainable nutrition solutions to safeguard nutrition security.

Keywords: vitamin D, 25-hydroxyvitamin D, nutrition, micronutrients, hidden hunger, nutrition security, nutritional pathways, nutrigenomics

\section{INTRODUCTION}

Vitamin D is needed to maintain calcium concentrations within a narrow physiological range. This function is vital as the calcium ion is essential for a large variety of cellular and metabolic processes in the body (Berridge, 2012). To secure the calcium supplies besides intestinal absorption, calcium is stored in the skeleton and acts as a large calcium reservoir that is mainly controlled by PTH and vitamin D (Bouillon et al., 2014). Humans produce vitamin $\mathrm{D}$ by exposure to sunlight that includes ultraviolet $B$ radiation; if ultraviolet $B$ radiation is not available in sufficient amounts, vitamin $\mathrm{D}$ needs to be obtained from the diet or dietary supplements (Holick, 2007). The start of the vitamin D endocrine system is believed to have been initiated before the start of vertebrates and evolved over millions of years 
(Bouillon and Suda, 2014). Therefore, the vitamin D micronutrient either synthesized through the sun by the skin or through dietary uptake is well-adapted to the human body. The endogenously conjugated vitamin $\mathrm{D}$ metabolites have taken over many important roles in the maintenance of human health, of which many still await to be discovered.

In this paper, we summarize the knowledge on vitamin $\mathrm{D}$ as an essential micronutrient important for human health and discuss the new nutritional research on its way to gain further knowledge on the function of vitamin $\mathrm{D}$ for nutrition.

\section{VITAMIN D PART OF NUTRITION AND CONTENT IN FOODS}

The history of vitamin D is linked to first scientific description of the classic bone disease rickets by Whistler in 1645 (Norman, 2012). Two centuries later it was Schütte who observed the usefulness of cod liver oil in the treatment of rickets and osteomalacia in 1824. The hunt for the anti-rachitic factor ended in early twentieth century, when Mellanby could demonstrate in a series of hallmark studies (1919-1924) that a nutritional component in the diet was the anti-rachitic factor to prevent rickets (Mellanby, 1919, 1976; Platt, 1956). Shortly after, vitamin D was inaugurated without the characterization of the chemical structure. In 1919, Hudschinsky showed in parallel that UV light was able to ameliorate rickets by increasing calcification in rachitic children (Huldschinsky, 1919, 1926). Both findings of the cod liver oil and the UV light preventing rickets remained independent observations until Hess and Weinstock elegantly could demonstrate that the anti-rachitic vitamin D was produce by UV irradiation in skin (Hess and Weinstock, 1925a,b). In 1936, Windaus and colleagues determined the chemical structure of the fat-soluble seco-steroid vitamin D (Windaus et al., 1936).

The vitamin $\mathrm{D}$ definition comprises a group of molecules called the calciferols. The main forms present in foods are cholecalciferol (vitamin $\mathrm{D}_{3}$ ) and ergocalciferol (vitamin $\mathrm{D}_{2}$ ), whereas the metabolite 25-hydroxycholecalciferol (25-hydroxyvitamin $\mathrm{D}_{3}$ ) is a natural part of the food chain by its occurrence in animal products. Vitamin $\mathrm{D}_{3}$ is unique by the fact that the same nutrient can be synthesized in the skin through the action of sunlight or being taken up by diet. This dual source of intake secures the body to maintain sufficient vitamin $\mathrm{D}$ levels in the body. The production in skin is usually the major vitamin $\mathrm{D}_{3}$ source for the body. However, in countries that receive insufficient sun exposure, people rely on dietary vitamin D as a major source. Exposure of the precursor 7-dehydrocholesterol in the basal and suprabasal layers of the epidermis to ultraviolet B (UVB) light with a wavelength of $290-315 \mathrm{~nm}$ is needed for the formation of the previtamin $\mathrm{D}_{3}$. The subsequent conversion is a non-enzymatic process that includes a thermal isomerization of the previtamin $\mathrm{D}_{3}$ to produce vitamin $\mathrm{D}_{3}$ (Collins and Norman, 2001; Holick, 2011). This vitamin $\mathrm{D}_{3}$ is rapidly converted to 25 -hydroxyvitamin $\mathrm{D}_{3}$ in the liver. The vitamin D status is evaluated by measuring the circulating levels of serum 25-hydroxyvitamin $\mathrm{D}$, which is the sum of cutaneous synthesis (vitamin $\mathrm{D}_{3}$ ) or dietary contribution (vitamin $\mathrm{D}_{3}$ and vitamin $\mathrm{D}_{2}$ ). The 25-hydroxyvitamin $\mathrm{D}_{3}$ needs to be further hydroxylated in the kidney (or locally in other organs Lehmann et al., 2001) to form 1,25-dihydroxyvitamin $\mathrm{D}_{3}$, the active endogenous hormone, which is responsible for most of the physiological actions of vitamin $\mathrm{D}$ through the binding to the vitamin $\mathrm{D}$ receptor (VDR). The plant-derived vitamin $\mathrm{D}_{2}$ is processed in the same way. For both vitamers, vitamin $\mathrm{D}_{2}$, and vitamin $D_{3}$, the consecutive molecular action is believed to be identical, whereas only 1,25-dihydroxy vitamin $\mathrm{D}_{3}$ is the endogenous hormone, the activated vitamer 1,25-dihydroxyvitamin $\mathrm{D}_{2}$ is hormone mimetic. Therefore, it was not surprising that vitamin $D_{3}$ has been reported to be superior to vitamin $D_{2}$ in terms of bioavailability and maintaining the vitamin $\mathrm{D}$ status by the majority of studies (Trang et al., 1998; Armas et al., 2004; Romagnoli et al., 2008; Glendenning et al., 2009; Heaney et al., 2011; Lehmann et al., 2013). Only one study reported that the two vitamers were essentially equipotent (Holick et al., 2008).

The level of cutaneous vitamin $\mathrm{D}_{3}$ synthesis is mainly affected by the amount of solar UVB radiation reaching the human skin, which is a function that needs to take into account the wavelength, thickness of the ozone layer in the atmosphere and solar zenith angle. Furthermore, the geographic latitude, season of the year and time of day influence and restrict the skin-borne synthesis of vitamin $\mathrm{D}_{3}$ (Webb et al., 1988; Holick, 2011). It was described that vitamin $D_{3}$ synthesis in the skin declines with age, which is due in part to a fall of 7-dehydrocholesterol and the morphological changes due to biological aging (MacLaughlin and Holick, 1985; Holick et al., 1989). Matsuoka et al. (1991) have shown that in Caucasians and Asian subjects having a lighter skin pigmentation UVB radiation produce significantly higher vitamin $\mathrm{D}_{3}$ serum levels than in African American and East Indian groups. It is not of a surprise that skin pigmentation reduces vitamin $\mathrm{D}_{3}$ formation. This skin tone dependent down regulation is easily overcome by increased sun exposures (Armas et al., 2007). Apart to darker pigmented skin, cutaneous vitamin $\mathrm{D}_{3}$ production can be reduced for many other reasons like severe air pollution in large cities, less outdoor activity as a consequence of an unhealthy lifestyle change, immobility of institutionalized elderly populations, topical application of sunscreens with a high sun protection factors or cultural dress codes (e.g., veiling). Therefore, dietary intake of vitamin D through foods or supplements plays a vital part to maintain healthy vitamin D levels.

Through nutrition, vitamin $\mathrm{D}$ intake is limited. There are few naturally-occurring food sources containing relevant levels of vitamin D. Table 1 summarizes the vitamin D content in selected foods. Vegetarian diets are limited to the plant vitamin $\mathrm{D}_{2}$ that is only present in some mushrooms. Commercially dark cultivated white button mushrooms contain low amounts of vitamin $\mathrm{D}_{2}$, only wild mushrooms or sun-dried mushrooms contain elevated amounts of ergocalciferol (Mattila et al., 1994, 1999b, 2001; Teichmann et al., 2007). Some commercial producers include an UVB radiation step to increase the vitamin $\mathrm{D}_{2}$ content in their products (Mau et al., 1998; Roberts et al., 2008). Vitamin $\mathrm{D}_{2}$ is formed out from ergosterol in the mushrooms. Some plants that are used as foods however can contain ergosterol, but this provitamin form is not converted to vitamin $\mathrm{D}_{2}$. Vitamin $\mathrm{D}_{3}$ is not found in food-borne plants. In plants, the occurrence of vitamin $\mathrm{D}_{3}$-related compounds is scarce. Interestingly, species belonging to the botanical Solanaceae family, like Solanum malacoxylon (Solanum glaucophyllum and Solanum glaucum), contain a glycoside of the active 1,25-dihydroxyvitamin $\mathrm{D}_{3}$ hormone 
Table 1 | Vitamin D content in raw products, processed foods, and fortified foods.

\begin{tabular}{|c|c|c|c|c|}
\hline \multirow[t]{2}{*}{ Category } & \multirow[t]{2}{*}{ Foodstuff } & \multicolumn{2}{|c|}{ Range } & \multirow[t]{2}{*}{ References } \\
\hline & & $\begin{array}{l}\text { ( } \mu \mathrm{g} \text { vitamin } D \\
\text { per } 100 \mathrm{~g})\end{array}$ & $\begin{array}{l}\text { (IU vitamin D } \\
\text { per } 100 \mathrm{~g} \text { ) }\end{array}$ & \\
\hline \multicolumn{5}{|c|}{ RAW PRODUCTS } \\
\hline \multirow[t]{5}{*}{ Fish } & Herring & $2.2-38.0$ & $88-1,520$ & $\begin{array}{l}\text { Kobayashi et al., 1995; Mattila et al., 1995a, 1997; Ostermeyer } \\
\text { and Schmidt, 2006; Byrdwell et al., } 2013\end{array}$ \\
\hline & Salmon & $4.2-34.5$ & $168-1,380$ & $\begin{array}{l}\text { Kobayashi et al., 1995; Ostermeyer and Schmidt, 2006; Lu et al., } \\
\text { 2007; Byrdwell et al., } 2013\end{array}$ \\
\hline & Perch & $0.3-25.2$ & $12-1,012$ & $\begin{array}{l}\text { Mattila et al., 1995a, 1997; Ostermeyer and Schmidt, 2006; } \\
\text { Byrdwell et al., } 2013\end{array}$ \\
\hline & Trout & $3.8-19.0$ & $152-760$ & $\begin{array}{l}\text { Mattila et al., 1995a; Ostermeyer and Schmidt, 2006; Byrdwell } \\
\text { et al., } 2013\end{array}$ \\
\hline & Tuna & $1.7-18.7$ & $68-748$ & $\begin{array}{l}\text { Takeuchi et al., 1984, 1986; Kobayashi et al., 1995; Byrdwell } \\
\text { et al., } 2013\end{array}$ \\
\hline \multirow[t]{3}{*}{ Mushrooms } & Morel & $4.2-6.3$ & $168-252$ & Phillips et al., 2011 \\
\hline & $\begin{array}{l}\text { Dark cultivated white } \\
\text { bottom mushrooms }\end{array}$ & $0-0.2$ & $0-8$ & Mattila et al., 2001; Teichmann et al., 2007; Phillips et al., 2011 \\
\hline & Wild grown mushrooms & $0.3-29.8$ & $10-1,192$ & $\begin{array}{l}\text { Mattila et al., 1994, 1999b, 2001; Kobayashi et al., 1995; } \\
\text { Teichmann et al., } 2007\end{array}$ \\
\hline \multirow[t]{3}{*}{ Animal products } & Pork meat & $0.1-0.7$ & $4-28$ & Kobayashi et al., 1995; Bilodeau et al., 2011; Strobel et al., 2013 \\
\hline & Beef meat & $0-0.95$ & $0-38$ & $\begin{array}{l}\text { Kobayashi et al., 1995; Montgomery et al., 2000, 2002; Bilodeau } \\
\text { et al., 2011; Strobel et al., } 2013\end{array}$ \\
\hline & Chicken meat & $0-0.3$ & $0-12$ & $\begin{array}{l}\text { Kobayashi et al., 1995; Mattila et al., 1995b; Bilodeau et al., 2011; } \\
\text { Strobel et al., } 2013\end{array}$ \\
\hline \multirow{4}{*}{ Fish } & Cod liver oil & $137.5-575.0$ & $5,500-23,000$ & Egaas and Lambertsen, 1979; Takeuchi et al., 1984 \\
\hline & Canned pink salmon & $12.7-43.5$ & $508-1,740$ & Bilodeau et al., 2011 \\
\hline & Canned sardines & $3.2-10$ & $128-400$ & Mattila et al., 1995a \\
\hline & Smoked salmon & $4.9-27.2$ & $196-1,088$ & Ostermeyer and Schmidt, 2006 \\
\hline Mushrooms & Irradiated mushrooms & $6.6-77.4$ & $264-3,094$ & Mau et al., 1998; Roberts et al., 2008 \\
\hline \multirow[t]{2}{*}{ Dairy } & Butter & $0.2-2.0$ & $8-80$ & $\begin{array}{l}\text { Kobayashi et al., 1995; Mattila et al., 1995b; Jakobsen and } \\
\text { Saxholt, } 2009\end{array}$ \\
\hline & Cheese & $0-0.1$ & $0-4$ & Mattila et al., 1995b; Wagner et al., 2008 \\
\hline \multicolumn{5}{|c|}{ FORTIFIED FOODS } \\
\hline Cereals & Corn flakes & $2-4.7$ & 87-189 & Haytowitz et al., 2009; U.S. Department of Agriculture, 2013 \\
\hline \multirow[t]{2}{*}{ Beverages } & Orange juice & 1.1 & 44 & Wacker and Holick, 2013 \\
\hline & $\begin{array}{l}\text { Malted drink mix, } \\
\text { powder }\end{array}$ & 3 & 123 & Haytowitz et al., 2009; U.S. Department of Agriculture, 2013 \\
\hline \multirow[t]{2}{*}{ Dairy } & Milk & $1.1-2.0$ & $42-79$ & $\begin{array}{l}\text { Calvo et al., 2004; Haytowitz et al., 2009; U.S. Department of } \\
\text { Agriculture, } 2013\end{array}$ \\
\hline & Cheese & $2.6-25.0$ & $102-1,000$ & $\begin{array}{l}\text { Haytowitz et al., 2009; Tippetts et al., 2012; U.S. Department of } \\
\text { Agriculture, } 2013\end{array}$ \\
\hline
\end{tabular}


(Boland, 1986; Boland et al., 2003; Japelt et al., 2013). This deciduous shrub (1.5-3.0 m stem length) is widely distributed in the provinces of Buenos Aires in Argentina and in Brazil and is responsible for the calcinotic disease in cattle and other grazing animal.

Animal food products are the main dietary source for naturally occurring vitamin $\mathrm{D}_{3}$ (Schmid and Walther, 2013). Since the discovery of vitamin $\mathrm{D}$, vitamin $\mathrm{D}$ was associated with oily fish products. It was driven by the early observation that the amount of vitamin D in a teaspoon of cod liver oil was sufficient to prevent rickets in infants. It is still the fish liver oil that contains the highest amounts of vitamin $\mathrm{D}_{3}$. The highest reported concentration was found in skipjack liver oil $144,400 \mu \mathrm{g} / 100 \mathrm{~g}$ (Takeuchi et al., 1984). The fish liver oils besides other nutritional ingredients might contain high levels of vitamin A. The vitamin A to vitamin $D$ ratio in the fish liver oils is species and fishing area dependent. The ratio range starts with a factor of 0.5 for skipjack liver oil and can even reach an extreme ratio of 119 (pollack liver oil) (Takeuchi et al., 1984). This wide vitamin A to vitamin D ratio range is the reason why fish liver oils often need further processing. In fresh fish products we observe a huge variation in the vitamin $\mathrm{D}_{3}$ content per $100 \mathrm{~g}$ wet weight (Egaas and Lambertsen, 1979; Takeuchi et al., 1984, 1986; Kobayashi et al., 1995; Mattila et al., 1995a, 1997; Ostermeyer and Schmidt, 2006; Lu et al., 2007; Byrdwell et al., 2013) (Table 1). Large variations in vitamin $\mathrm{D}_{3}$ content were found within the same species, but also between the different fish species. Fish obtain their vitamin $\mathrm{D}_{3}$ requirements through their diet (Holick, 2003). Therefore, the vitamin $\mathrm{D}_{3}$ levels in the zooplankton, the primary food source of fish, or seasonal changes in the zooplankton reservoirs in the different habitats, might be the reasons for the observed fluctuation in the fish product. Interestingly, the weight, the sex, or the age of the fish could not be correlated to the vitamin $\mathrm{D}_{3}$ content. Furthermore, no significant correlation between the tissue fat content and vitamin $\mathrm{D}$ levels was detected (Mattila et al., 1995a, 1997). Significant differences in vitamin $\mathrm{D}_{3}$ content were found between muscle and skin tissues and even more pronounced between muscle and liver tissues (Takeuchi et al., 1986). The 25-hydroxyvitamin $\mathrm{D}_{3}$ compound was also detected, though at low concentrations (Takeuchi et al., 1986; Mattila et al., 1995a; Ovesen et al., 2003; Bilodeau et al., 2011).

Wild and sun-dried mushrooms can be a good dietary source of vitamin $D_{2}$ (Mattila et al., 1994, 1999b, 2001; Kobayashi et al., 1995; Teichmann et al., 2007; Phillips et al., 2011). However, the commercially produced mushrooms, e.g., the white button mushroom, do not contain or contain only very low amounts of vitamin $\mathrm{D}_{2}$ (Mattila et al., 2001; Teichmann et al., 2007; Phillips et al., 2011). The vitamin $\mathrm{D}_{2}$ content in commercially produced mushrooms can be increased by UVB exposure during the culturing or the postharvest process (Mau et al., 1998; Roberts et al., 2008). The concentration of vitamin $D$ in eggs can vary from 0.4 to $12.1 \mu \mathrm{g}$ (Parrish, 1979; Mattila et al., 1992, 1999a; Bilodeau et al., 2011; Exler et al., 2013), it is in a similar range like offal (Mattila et al., 1995b; Montgomery et al., 2000, 2002). Other animal products like pork, beef, and chicken muscle meat are low in vitamin D content (Mattila et al., 1995b; Montgomery et al., 2000, 2002; Bilodeau et al., 2011; Strobel et al., 2013). By adding vitamin $\mathrm{D}_{3}$ into the feed, the vitamin $\mathrm{D}_{3}$ content can be increased in muscle and liver of cattle, to $4.6 \mu \mathrm{g}$ per $100 \mathrm{~g}$ of tissue and $99.6 \mu \mathrm{g}$ per $100 \mathrm{~g}$ of tissue, respectively (Montgomery et al., 2004). Milk, unless fortified, has been shown to contain no or very little amounts of vitamin D, whereas in dairy products like butter and cheese the vitamin D content is higher, but in serving size amounts still very low (Kobayashi et al., 1995; Mattila et al., 1995b; Jakobsen and Saxholt, 2009; Trenerry et al., 2011). In general, household cooking seems to have some effect on vitamin D stability depending on the actual foodstuffs and the heating process used (Mattila et al., 1999b; Jakobsen and Knuthsen, 2014).

To meet the vitamin $\mathrm{D}$ needs in the countries some states fortify foods. Dairy products are ideal for vitamin D fortification. In Canada vitamin D fortification is mandatory for milk $(1 \mu \mathrm{g} / 100 \mathrm{ml})$ and margarine $(13.3 \mu \mathrm{g} / 100 \mathrm{~g})$ (Health Canada, 2014). In other countries, like the United States, vitamin D fortification is optional for products like milk, breakfast cereals, and fruit juices (Calvo et al., 2004). In the U.S. Department of Agriculture (2013) of the US Department of Agriculture (USDA)'s Nutrient Databank System (Haytowitz et al., 2009), 5036 foods have been determined for their vitamin D content, of which only 259 food items had detectable vitamin D levels. The data showed that per serving only seven fish products had $>15 \mu \mathrm{g}$ vitamin D. All 29 foods that contained between $2.5 \mu \mathrm{g} 15 \mu \mathrm{g}$ vitamin D per serving were either fortified foods (21) or fish produce (8). Two-thirds of all vitamin D containing foods were far below the $1.0 \mu \mathrm{g}$ level, whereas 20 percent had even negligible vitamin D content per serving (below $0.1 \mu \mathrm{g}$ ).

Despite the fact that moderate sun exposure of arms and legs in summer for 5-30 min between the hours of 10 a.m. and 3 p.m. twice a week is enough to produce sufficient vitamin $\mathrm{D}_{3}$ in the body (Holick, 2007), it is astonishing that many populations that live at these privileged latitudes fail to achieve this goal (Holick and Chen, 2008; Lips, 2010; Wahl et al., 2012; Hilger et al., 2014). During winter time, when vitamin $\mathrm{D}_{3}$ production by the sun ceased, adequate vitamin D levels can only be achieved by UVB exposure from indoor tanning units, or by a daily diet of fortified foods or a few selected food items. This restricted list of options to achieve sufficient levels is one of the reasons, why the use of dietary vitamin D supplements has become so popular. It is currently the most applied and secure option to reach adequate vitamin D intake levels (Holick, 2007).

\section{VITAMIN D MAP, MALNUTRITION, HIDDEN HUNGER, AND NUTRITION SECURITY}

An accepted biomarker for the vitamin D status in the general population is to measure the serum concentration of 25-hydroxyvitamin D levels, which is the major circulating form of vitamin $\mathrm{D}$ and reflects both dietary vitamin $\mathrm{D}$ intake and the endogenous vitamin D production (Lips, 2001, 2007). The serum concentration of 25-hydroxyvitamin D is linked to the serum level of the active hormone 1,25-dihydroxyvitamin D and also to the clinical relevant parathyroid hormone level. Lips has classified the 25-hydroxyvitamin D levels into four stages (Lips, 2001; Lips et al., 2013): severe deficiency $(<12.5 \mathrm{nmol} / \mathrm{L})$, deficiency $(12.5-25 \mathrm{nmol} / \mathrm{L})$, insufficiency $(25-50 \mathrm{nmol} / \mathrm{L})$, repletion 
(>50 nmol/L). The thresholds for severe deficiency and deficiency are undisputed; however, a controversy has arisen for defining the border between insufficiency and repletion. In 2011, the Institute of Medicine (IOM) suggested a serum level of $50 \mathrm{nmol} / \mathrm{L}$ as the value at which $97.5 \%$ of the vitamin $\mathrm{D}$ needs of the population would be covered (Institute of Medicine, 2011; Ross et al., 2011), whereas, the Endocrine Society (ES) defined it to be higher: $75 \mathrm{nmol} / \mathrm{L}$ (Holick et al., 2011). All deficiency levels including insufficiency, as so-called mild deficiency, must be prevented through focused supplementation.

In 2010, the Institute of Medicine (IOM) introduced new dietary reference intake (DRI) values for vitamin D after comprehensive reviewing of more than 1000 high quality research articles to renew thereby their first settings from 1997 (Institute of Medicine, 2011). The DRIs address an adequate nutritional intake of all sources. The IOM has set the dietary allowance (RDA) to 600 IU per day for the general population and at $800 \mathrm{IU}$ per day for persons 70 years and older, whereas 1 IU is the biological equivalent of $0.025 \mu \mathrm{g}$ vitamin $\mathrm{D}_{3}$. The tolerable upper intake level or UL (Upper Level of Intake), which represents the safe upper limit, was set to $4000 \mathrm{IU}$ per day for vitamin D intake (Ross et al., 2011). The new RDAs reflect the scientific outcome from large dietary studies that revealed vitamin D insufficiency (Looker et al., 2002; Zadshir et al., 2005). In 2012, Troesch et al. analyzed the vitamin intake from different dietary surveys that included the German Nutritional Intake Study (Nationale Verzehrstudie II) 2008 (Max Rubner-Institut, 2008), the US National Health and Nutrition Examination Survey (NHANES) from 2003 to 2008 (Centers for Disease Control and Prevention \& National Center for Health Statistics, 2009), the UK (The British National Diet and Nutrition Survey, 2003) (Henderson et al., 2003) and the Netherlands (van Rossum et al., 2011), and could confirm that vitamin D is one of the critical vitamins, which intake is below the recommendation (Troesch et al., 2012).

A gap exists between the intake and the recommendation of vitamin D. The chronic insufficient intake of micronutrients like vitamin D without seeing immediate clinical signs is called Hidden Hunger. Hidden Hunger, in particular for vitamin D, is more prevalent in the populations of the developed countries as anticipated (Biesalski, 2013). Hidden Hunger is a threat for the nutrition security for a given country. Nutrition security mandates sufficient micronutrients in an adequate food supply and is required to safeguard an optimal nutritional status of a population.

Many groups have identified vitamin D deficiency or insufficiency to become a public health problem worldwide (Holick, 2007; Holick and Chen, 2008; Mithal et al., 2009; Lips and Van Schoor, 2011; Wahl et al., 2012; Hilger et al., 2014). Mithal et al. (2009) described in their global report that most populations do not achieve a desirable vitamin $\mathrm{D}$ status and particular people at risk and elderly people suffer from vitamin D deficiency. In two reports, the International Osteoporosis Foundation (IOF) and its partners published the global vitamin D status map (Wahl et al., 2012; Hilger et al., 2014). The vitamin D map was based on a systematic review of the worldwide vitamin D levels, using all available publications published between 1990 and February 2011 (Hilger et al., 2014). Eligible studies include 168,389 participants from the general populations throughout the world where the mean or median serum 25-hydroxyvitamin D levels were measured. Studies included had a cross-sectional design or were based on a population based cohorts. The analysis identified nearly 200 studies from 44 countries, whereas only half of the studies were included in the global vitamin D status map as $50.2 \%$ of the studies were not representative for the target populations. Figure 1 shows the global vitamin D status map listed by countries and by continents. The largest numbers of studies were performed in Europe, followed by North America and AsiaPacific. Available data from Latin America and even more from Africa are limited. Results of this review showed that $6.7 \%$ of the population were vitamin D deficient (mean 25-hydroxyvitamin D values $<25 \mathrm{nmol} / \mathrm{L}$ ), $37.3 \%$ were vitamin $\mathrm{D}$ insufficient according to IOM (mean values below $50 \mathrm{nmol} / \mathrm{L}$ ) and $88.1 \%$ of the population showed an insufficient vitamin D status according to the ES (mean values below $75 \mathrm{nmol} / \mathrm{L}$ ). No significant differences were found for gender or age, when looking at the worldwide data, but some regional differences could be identified (Hilger et al., 2014). The 25-hydroxyvitamin D serum levels were higher in Europe and the US, when compared to Middle East and Africa. This might be due to the vitamin $\mathrm{D}$ food fortification programs in North America (Prentice, 2008). Furthermore, the systematic analysis revealed that institutionalized elderly were more at risk to have low 25-hydroxyvitamin D levels in Europe and Asia/Pacific. The compared non-institutionalized elderly group showed higher levels, possibly due to spending more of time outdoors. The group of institutionalized elderly is therefore at high risk to become vitamin D deficient. Further research is needed to inform public health policy makers to reduce the risk for potential health consequences of low vitamin D status.

In the past few years the national recommendations for dietary vitamin D were adjusted in several countries; they are not harmonized across the European Union yet and vary from 200 to 800 IU. The higher recommendations for dietary vitamin D intake are increasingly being suggested in government documents, position statements and clinical practice guidelines for bone health. In 2008, the US Food and Drug Administration updated the health claim for the prevention of osteoporosis by including vitamin D to the consumption of calcium (Food and Drug Administration, 2008). In 2008, the American Academy of Pediatrics also reacted and issued an update of their guidelines for vitamin D intake and rickets prevention (Perrine et al., 2010). They doubled the recommended dose of vitamin D for children to 400 IU per day, beginning in the first few days of life and continuing throughout adolescence. In 2010, the Institute of Medicine (IOM) released the revised Dietary Reference Intakes (DRI's) for calcium and vitamin $\mathrm{D}$ and tripled the recommendations for vitamin $\mathrm{D}$ intakes to 600 IU per day for children and all adults up to age 69 years (Institute of Medicine, 2011). The IOM stated that there was insufficient evidence to make recommendations for non-skeletal benefits.

In 2012, the German, Austrian, and Swiss Nutrition Societies raised the recommended vitamin D intake to $800 \mathrm{IU}$ per day, in case of absent UVB exposure, for all age groups starting from 1 year of age (German Nutrition Society, 2012). Furthermore, key opinion leaders are increasingly recommending higher daily intakes for vitamin D, between 800 and $1000 \mathrm{IU}$ or even higher for people at risk or older adults. The recent statement by the IOF and the guidelines by the US ES suggest that higher vitamin D doses 

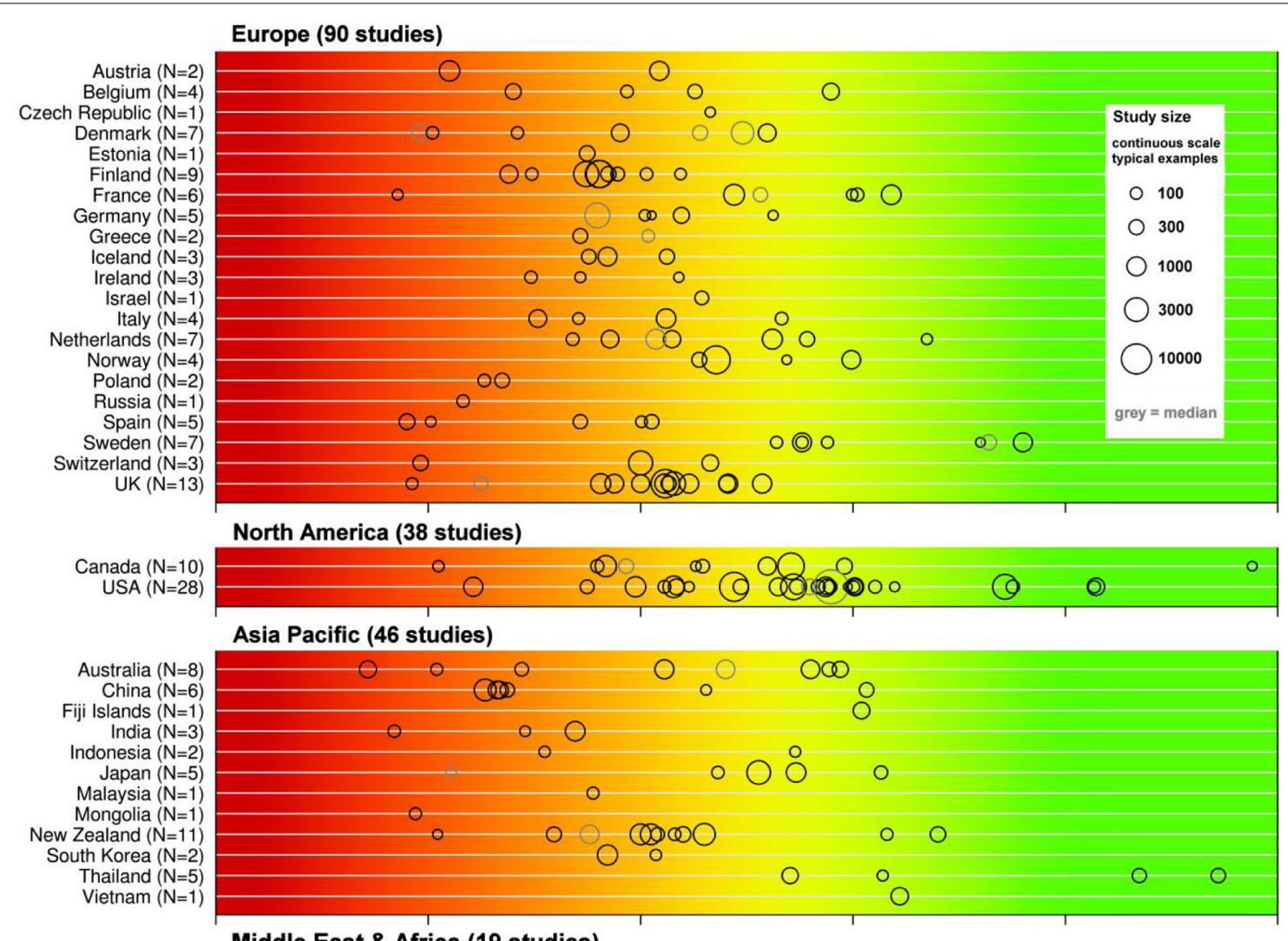

Middle East \& Africa (19 studies)

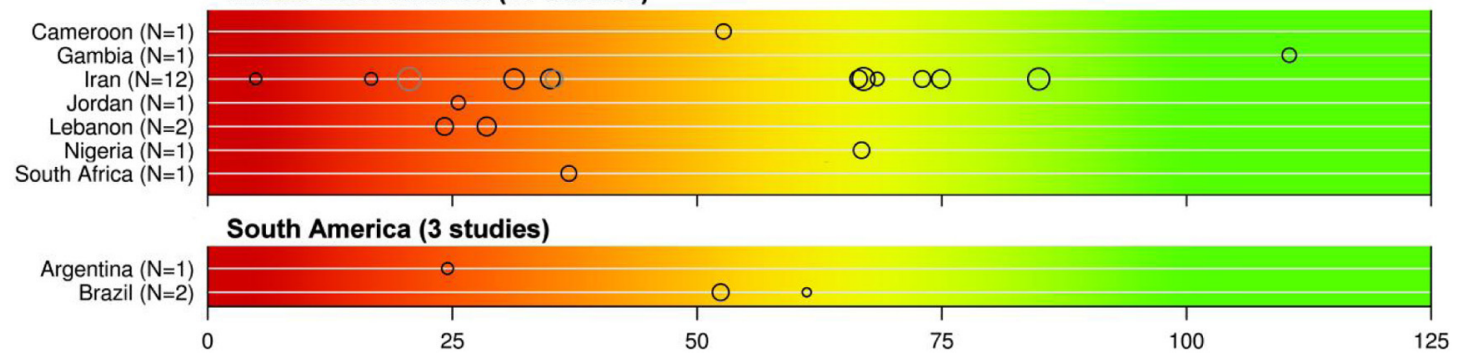

FIGURE 1 | Overview of published 25-hydroxyvitamin D mean/median values by countries (modified from Hilger et al., 2014). The color trend from red, yellow to green shown above the graphical diagram represents the current uncertainty around the definition of

25-hydroxyvitamin $D_{3}$ serum thresholds starting from severe deficiency (red), deficiency, insufficiency to total repletion (green). The reported means are shown as black circles, studies that reported medians are given in gray circle. The study size is indicated by the circle size. Mean/median values falling within the intensely red zone are most consistent with severe vitamin D deficiency. would be needed to achieve the desirable 25-hydroxyvitamin D serum level of $75 \mathrm{nmol} / \mathrm{L}$ for people at risk or older individuals.

Increasing the vitamin $\mathrm{D}$ levels in the population would also ameliorate health economics. Grant and colleagues calculated the benefit of increasing vitamin $\mathrm{D}$ levels to reduce the economic burden of diseases (Grant et al., 2009). A rise in the vitamin D serum level of all Europeans to $40 \mathrm{nmol} / \mathrm{L}$ would reduce the economic burden of different diseases and could save health care costs of up to $16.7 \%$. Besides reducing the economic costs, vitamin $\mathrm{D}$ intake could in addition also reduce mortality rates and maintain a longer healthy life style.

\section{NUTRITIONAL RESEARCH TO ADDRESS AND UNDERSTAND VITAMIN D INSUFFICIENCY}

Vitamin D deficiency is undoubtedly linked to severe consequences in the growing child by causing incomplete mineralization of the bone and in the adult accounting to wasteful osteomalacia. In the vitamin D insufficiency stage, this severity gets gradually less, but the outcome remains unchanged. Besides the established and accepted functional skeletal health relationship, more and more evidence is accumulating for falls (Pfeifer et al., 2000, 2009; Bischoff et al., 2003; Flicker et al., 2005; Broe et al., 2007; Prince et al., 2008; Bischoff-Ferrari et al., 2009) and physical performance (Bischoff-Ferrari et al., 2004; Houston et al., 2011; Ceglia et al., 2013; Redzic et al., 2013; Sohl et al., 2013; 
Tieland et al., 2013), which has been recognized by a health claim of the European Food and Safety Authority in 2011: "Vitamin D may reduce the risk of falling. Falling is a risk factor for bone fractures." This health claim is targeting men and women 60 years of age and older and the dose required is a daily consumption of 800 IU vitamin D, which can come from all sources. Further emerging vitamin D health relationships include physiological parameters like improved immune response (Baeke et al., 2010; Schwalfenberg, 2011; Hewison, 2012; White, 2012), improved respiratory health(Berry et al., 2011; Charan et al., 2012; Choi et al., 2013; Hirani, 2013) possibly also relate to reduced tuberculosis incidence (Nnoaham and Clarke, 2008; Martineau et al., 2011; Mitchell et al., 2011; Coussens et al., 2012; Salahuddin et al., 2013; Huaman et al., 2014); and reduced risk to develop autoimmune diseases like multiple sclerosis (Solomon and Whitham, 2010; Cantorna, 2012; Dobson et al., 2013) or type 1 diabetes (Hypponen et al., 2001; Holick, 2003; Ramos-Lopez et al., 2006; Baeke et al., 2010; De Boer et al., 2012; Dong et al., 2013; Van Belle et al., 2013). In chronic, non-communicable diseases, vitamin D deficiency is being discussed to possibly ameliorate the incidence of some neoplastic diseases like colorectal, lung, prostate, and breast cancers ( $\mathrm{Ng}$ et al., 2008; Rosen et al., 2012; Welsh, 2012; Cheng et al., 2013); cardiovascular diseases (CVDs) including hypertension, myocardial infarction, stroke (Forman et al., 2007; Giovannucci et al., 2008; Gardner et al., 2011; Bischoff-Ferrari et al., 2012; Tamez and Thadhani, 2012; Karakas et al., 2013; Pilz et al., 2013a; Schroten et al., 2013); life-style diseases like obesity and type 2 diabetes (Pittas et al., 2007; González-Molero et al., 2012; Khan et al., 2013; Pilz et al., 2013b; Schottker et al., 2013; Tsur et al., 2013; Van Belle et al., 2013; Bouillon et al., 2014); diseases related to the decline in sight function including age-related macular degeneration (Parekh et al., 2007; Millen et al., 2011; Lee et al., 2012); and neurological disorders including Alzheimer and Parkinson disease (Buell and Dawson-Hughes, 2008; Annweiler et al., 2012; Eyles et al., 2013; Zhao et al., 2013). One may wonder about the width of possible implications being looked at, but considering the more than 1000 genes which vitamin D is regulating through the VDR (Carlberg and Campbell, 2013), this may actually not be a surprise. To determine the potential role of vitamin D supplementation in the prevention or treatment of chronic nonskeletal diseases notwithstanding, large-scale clinical trials are demanded. In this respect for the nutrition field, four new largescale ongoing long-term supplementation studies are expected to deliver results in near future (Table 2 ). The two very large studies, VITAL trial $(n=20,000)$ and FIND study $(n=18,000)$, are meant to deliver clinical evidence for the effect of vitamin $D_{3}$ on cancer, CVD and diabetes outcomes. The two smaller trials, CAPS and DO-HEALTH, each having more than 2,000 participants are including cancer, infections, fractures, hypertension, cognitive function, and physical performance outcomes. In all four studies the placebo group will produce vitamin $\mathrm{D}_{3}$ in the skin and will possibly consume vitamin $\mathrm{D}$ through food, and therefore this will narrow the vitamin $\mathrm{D}$ serum level gap between the placebo and treatment groups. It remains to be seen whether the applied supplementation doses (2000 IU and 1600 IU, 3200 IU) will be sufficient to see a clear difference between the treatment and the control groups. An open likelihood will remain for the placebo group potentially obtaining sufficient vitamin $\mathrm{D}_{3}(600-$ $800 \mathrm{IU})$ levels that are considered to be sufficient for skeletal effects. In such a case only an incremental increase of an additional $\sim 1000$ IU can be considered as the effective dose, for which no power calculation was available at the time before study begun. In light of such a situation, it will be of interest whether the micronutrient triage theory of Bruce Ames can be validated with vitamin $\mathrm{D}_{3}$ (Ames, 2006; McCann and Ames, 2009). The triage theory postulates, as a result of recurrent shortages of micronutrients during evolution, that the body has selected and developed a metabolic rebalancing response to shortage. These rebalancing favored micronutrient-needs for short term survival, while those only required for long-term health were starved. In the case of the micronutrient vitamin $\mathrm{D}_{3}$, calcium and bone metabolism can be considered to be secured with highest priority, therefore, it might be speculated that the 600-800 IU intake would satisfy this vitamin $\mathrm{D}_{3}$ serum level threshold. For the chronic non-skeletal diseases however, which have only secondary priority in an evolutionary perspective, higher serum vitamin $\mathrm{D}_{3}$ levels would be required. The ongoing four vitamin $\mathrm{D}_{3}$ studies that have chronic diseases as their main outcomes and use nutritionally relevant $\sim 2000$ IU are therefore well-suited to address whether the triage theory holds also true for the micronutrient vitamin $\mathrm{D}_{3}$.

Vitamin $\mathrm{D}_{3}$ once in the blood immediately binds to the vitamin D-binding protein (DBP) and gets transported into the liver (Holick, 2007). The first hydroxylation at position 25 generates the major circulating metabolites 25-hydroxyvitamin $\mathrm{D}_{3}$. This metabolite circulates throughout all organs and undergoes hydroxylation at position 1 , which occurs mainly in the kidney, but also in other organs, to form 1,25-dihydroxyvitamin $\mathrm{D}_{3}$, the active hormone. Besides the major circulating metabolite 25-hydroxyvitamin $\mathrm{D}_{3}$ and the hormonally active metabolite 1,25-dihydroxyvitamin $\mathrm{D}_{3}$, more than 35 additional vitamin $\mathrm{D}_{3}$ metabolites are formed by the body (Bouillon et al., 1995; Norman et al., 2001). It is speculated that they might be intermediates in the catabolism of 1,25-dihydroxyvitamin $\mathrm{D}_{3}$. The human body has evolved many CYP enzymes and invests energy to form these additional 35 vitamin $\mathrm{D}_{3}$ metabolites, whether this is for the purpose to catabolize 1,25-dihydroxyvitamin $\mathrm{D}_{3}$, remains still to be answered. More appealing is the theory that these metabolites are formed to fulfill yet unknown functions of vitamin $D_{3}$. This perspective could potentially also account to the pleiotropic nonskeletal health benefits reported by the many vitamin $D$ intake studies. For some of the vitamin $\mathrm{D}_{3}$ metabolites like the 24R,25dihydroxyvitamin $\mathrm{D}_{3}$ potential function was explored in vitro (Norman et al., 2002).

The 24R,25-dihydroxyvitamin $\mathrm{D}_{3}$ has been shown to be an essential hormone in the process of bone fracture healing. The 24R,25-dihydroxyvitamin $\mathrm{D}_{3}$ most likely initiates its biological responses via binding to the ligand binding domain of a postulated cell membrane receptor $\mathrm{VDR}_{\mathrm{mem} 24,25}$, similar to the better studied, but still not cloned cell membrane receptor for 1,25dihydroxyvitamin $\mathrm{D}_{3}, \mathrm{VDR}_{\mathrm{mem} 1,25}$ (Norman et al., 2002). From the nutritional point of view, it will be of interest to investigate the function of the all vitamin $\mathrm{D}_{3}$ metabolites and relate the function to the level of vitamin $\mathrm{D}_{3}$ intake to secure the health benefit according to the triage theory. 


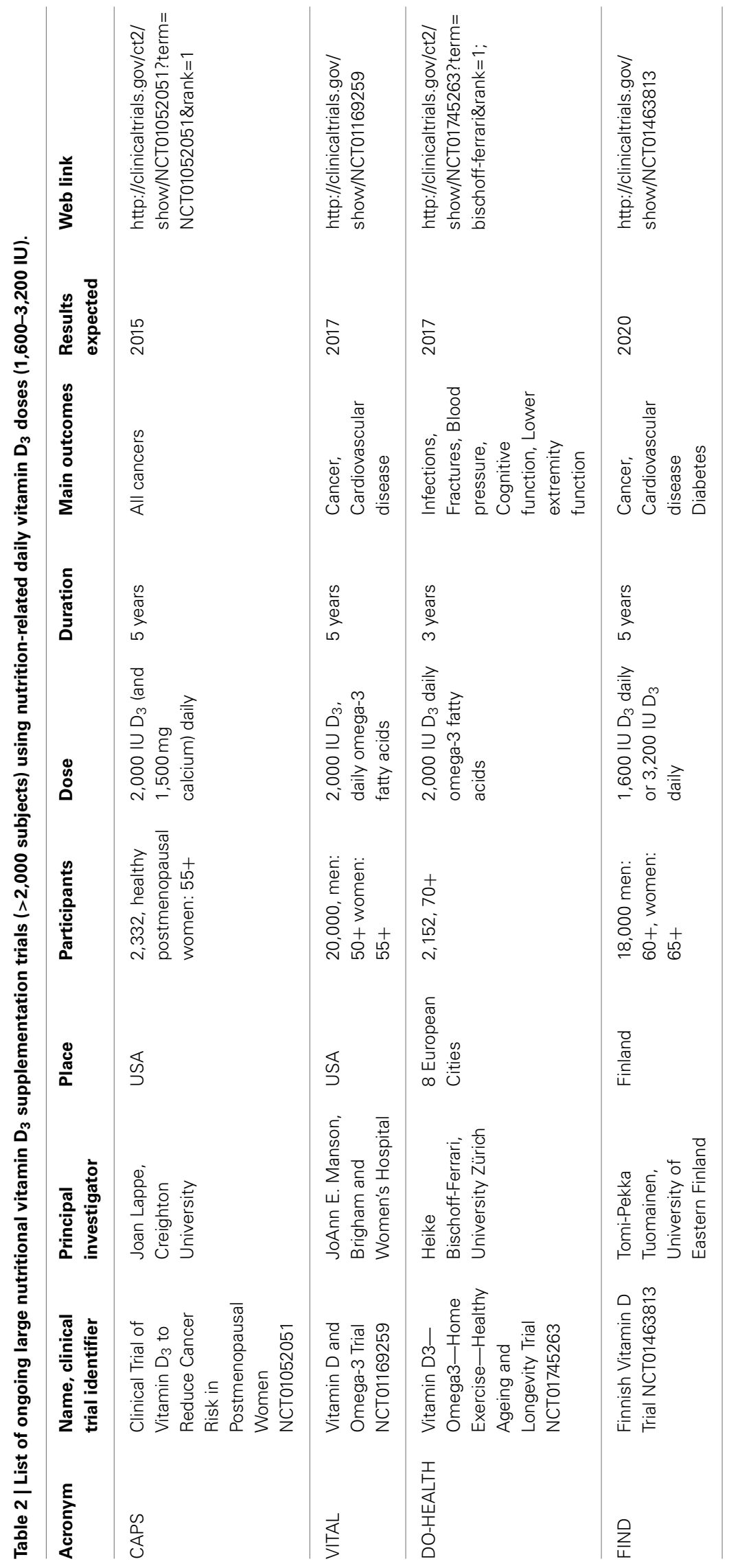


According to the current knowledge, the vitamin D endocrine system is funneled through the biologically most active metabolite 1,25-dihydroxyvitamin $\mathrm{D}_{3}$ that is mainly produced in the kidney, but also in other organs (Bouillon et al., 2013). Mechanistically 1,25-dihydroxyvitamin $\mathrm{D}_{3}$ binds the VDR directly on a DNA sequence, the 1,25-dihydroxyvitamin $\mathrm{D}_{3}$ response element (VDRE), in the regulatory region of primary 1,25-dihydroxyvitamin $\mathrm{D}_{3}$ target genes (Carlberg and Campbell, 2013). The VDR forms together with the retinoid $\mathrm{X}$ receptor or putative other transcription factors a heterodimer on the VDRE, recruiting tissue-specific transcriptional co-activators and regulates through a conformational change upon 1,25-dihydroxyvitamin $\mathrm{D}_{3}$ binding the downstream gene. The VDR is widespread in more than 30 tissues (Bouillon et al., 1995) and may trigger expression of more than 1000 genes through 1,25-dihydroxyvitamin (Carlberg et al., 2013; HosseinNezhad et al., 2013). The regulation of tissue-specific gene expression by 1,25 -dihydroxyvitamin $\mathrm{D}_{3}$ is of high interest, as it guides us toward the better understanding of the mechanistic action of vitamin $\mathrm{D}_{3}$ in the different tissues. The gained knowledge from the mechanistic studies can help to design smaller and more focused nutritional intervention RCTs to answer whether vitamin $\mathrm{D}$ contributes to a specific health benefit of interest. In this respect the GeneChip-based transcriptomics methodology using high-density microarrays demonstrated the expression of genes in a variety of important functions of more than 100 different pathways that could be linked to vitamin D deficiency (Bossé et al., 2007; Tarroni et al., 2012; Hossein-Nezhad et al., 2013). The development of chromatin immunoprecipitation (ChiP) methodology linked to site-specific PCR amplification of the VDR bound genomic DNA fragment, and later the methods using tiled microarrays (ChiP-chip) applying the first unbiased genome-wide approach, which then was followed by the massive parallel NGS sequencing approach of the immunoprecipitated DNA segments, opened up new avenues to investigate 1,25-dihydroxyvitamin $\mathrm{D}_{3}$ target genes in selected tissues (Ramagopalan et al., 2010; Heikkinen et al., 2011; Carlberg et al., 2012, 2013; Pike et al., 2014). In an elegant study, Carlberg et al. identified in samples of 71 pre-diabetic individuals of the VitDmet study changes in serum 25-hydroxyvitamin $\mathrm{D}_{3}$ concentrations that were associated to primary vitamin $\mathrm{D}$ target genes (Carlberg et al., 2013). Based on their finding the authors proposed the genes CD14 and THBD as transcriptomics biomarkers, from which the effects of a successful vitamin $\mathrm{D}_{3}$ supplementation can be evaluated. These biomarkers are potentially suitable for displaying the transcriptomics response of human tissues to vitamin $\mathrm{D}_{3}$ supplementation.

Epigenetic alterations of the genome refer to heritable and modifiable changes in gene expression that are not affecting the DNA sequence. They may be inherited as Mendelian, non-Mendelian, or environmentally caused traits. One of the 1,25-dihydroxyvitamin $\mathrm{D}_{3}$ induced epigenetic modification was shown for the hypo-methylating effect on the osteocalcin promoter (Haslberger et al., 2006). 1,25-Dihydroxyvitamin $\mathrm{D}_{3}$ was associated with the demethylation of the osteocalcin promoter and induced the osteocalcin gene expression. The activity of VDR can be modulated by epigenetic histone acetylation. The
VDR alone or in concert with other transcription factors can recruit histone-modifying enzymes like histone acetyl transferases (HATs) or histone deacetylases (HDACs) and epigenically direct transcriptional expression of downstream genes (Burrell et al., 2011; Karlic and Varga, 2011; Sundar and Rahman, 2011; Hossein-Nezhad et al., 2013). The trans-generational epigenetic inheritance of vitamin $\mathrm{D}_{3}$ triggered epigenome modification is not fully explored, however maternal vitamin $\mathrm{D}$ deficiency has been discussed with adverse pregnancy outcomes or potential susceptibility for diseases (Burrell et al., 2011; Hossein-Nezhad and Holick, 2012). For future nutritional research it would be of great value to identify and validate epigenetic biomarkers that could serve as risk assessment tool for vitamin D insufficiency related susceptibility to develop a disease later in life.

Variations in vitamin D status have been shown to be related to inheritance. The disparity of vitamin $\mathrm{D}$ levels according to ethnicity given skin pigmentation is well-established (Cashman, 2014; Ng et al., 2014). Dark skinned population individuals have compared to Caucasian descendants almost one-half the serum concentrations of 25-hydroxyvitamin D (Nesby-O'dell et al., 2002). From twin studies it has been estimated that the heritability of genetic regulation of vitamin $\mathrm{D}$ levels to be between 23 and $80 \%$ (Dastani et al., 2013). In addition, large-scale genetic association studies using linkage disequilibrium analysis have identified genetic loci correlating with serum vitamin D level within five candidate genes (Dastani et al., 2013). The identified SNPs are within the 1alpha-hydroxylase of 25-hydroxyvitamin $\mathrm{D}$ (CYP27B1) gene, the 25-hydroxylase of vitamin D (CYP2R1) gene, the vitamin D carrier protein (GC) gene, the VDR gene, and the cytochrome P-450 (CYP24A1) gene coding for an enzyme that inactivates 1,25 -dihydroxyvitamin $\mathrm{D}$. It is important to note that replication studies in separate populations have to follow to verify the validity of the identified SNPs. The SNP information will provide the additional guidance toward a personalized nutritional advice to reach a sufficient vitamin D status.

\section{CONCLUSION AND FUTURE PERSPECTIVES}

In the recent years the knowledge about vitamin D and its implications have extended far beyond its classical role in bone health in either fields of basic research as well as in human trials. In particular, the evidence for the role of vitamin D in reducing the risk of fractures as well as decreasing the risk for falling is convincing and authorities have responded to it. Besides a health claim issued by the EFSA on the risk reduction for falling the dietary intake recommendations have been significantly increased in several countries such as the US and in Europe (Austria, Germany, Switzerland). A number of other countries around the globe are in the process of establishing new dietary intake recommendations as well. It turns out that on average a daily intake of 600-800 IU vitamin $\mathrm{D}$ appears to be required to meet fundamental needs of the human body, for specific applications higher daily intakes may be necessary, which will become clearer as the results of a number of ongoing clinical studies will become available.

The obvious question to answer is: do people obtain the recommended amounts of vitamin $\mathrm{D}$ ? The diet is typically only a minor vitamin $\mathrm{D}$ source as only few food items contain relevant amounts of vitamin $\mathrm{D}$, such as fatty sea fish. The primary vitamin 
D source for humans is the vitamin D synthesis in the skin from vitamin D precursors by the sunlight-provided the skin is sufficiently exposed to strong enough sun radiation. Several groups have reviewed the published results on 25-hydroxyvitamin D serum levels the established marker of the vitamin D status, showing that low 25-hydroxyvitamin D levels are found in many cohorts around the world. A recent systematic review of the global vitamin D status (Hilger et al., 2014) showed that $6.7 \%$ of the overall populations reported deficient 25 -hydroxyvitamin $\mathrm{D}$ levels below $25 \mathrm{nmol} / \mathrm{L}, 37 \%$ had 25-hydroxyvitamin D levels below $50 \mathrm{nmol} / \mathrm{L}$, and only $11 \%$ were above $75 \mathrm{nmol} / \mathrm{L}$, which is considered an adequate status by the IOF and the ES. So a very important task ahead of us is to find efficient ways to improve the vitamin D status on the population level, be it by dietary means, food fortification, or dietary supplements.

In addition, it will be very important to gather sound and convincing evidence for the many additional implicated health benefits of vitamin $\mathrm{D}$ besides the ones that already reached a health claim status and to see which of them will actually hold up. This will require appropriate human studies on the one hand, and also involve the appropriate use of the novel experimental approaches like nutrigenomics, nutrigenetics, and nutriepigenetics on the other hand. In conclusion, the evidence we have for vitamin $\mathrm{D}$ in human health is exciting, however we have to make sure that appropriate measures are taken to improve the vitamin $\mathrm{D}$ status to the levels required to be beneficial for human health. In future, we will also need to further apply, exploit and invest in novel, innovative and break-through technologies in the vitamin $\mathrm{D}$ research to understand the underlying mechanisms by which vitamin $\mathrm{D}$ is exerting so many effects in the human body, which is knowledge needed to the purpose to obtain and secure optimal public health through nutrition.

\section{REFERENCES}

Ames, B. N. (2006). Low micronutrient intake may accelerate the degenerative diseases of aging through allocation of scarce micronutrients by triage. Proc. Natl. Acad. Sci. U.S.A. 103, 17589-17594. doi: 10.1073/pnas.0608757103

Aminullah Bhuiyan, A. K. M., Ratnayake, W. M. N., and Ackman, R. G. (1993). Nutritional composition of raw and smoked atlantic mackerel (scomber scombrus): oil- and water-soluble vitamins. J. Food Compos. Anal. 6, 172-184. doi: 10.1006/jfca.1993.1019

Annweiler, C., Rolland, Y., Schott, A. M., Blain, H., Vellas, B., Herrmann, F. R., et al. (2012). Higher vitamin D dietary intake is associated with lower risk of Alzheimer's disease: a 7-year follow-up. J. Gerontol. A Biol. Sci. Med. Sci. 67, 1205-1211. doi: 10.1093/gerona/gls107

Armas, L. A., Dowell, S., Akhter, M., Duthuluru, S., Huerter, C., Hollis, B. W., et al. (2007). Ultraviolet-B radiation increases serum 25-hydroxyvitamin D levels: the effect of UVB dose and skin color. J. Am. Acad. Dermatol. 57, 588-593. doi: 10.1016/j.jaad.2007.03.004

Armas, L. A., Hollis, B. W., and Heaney, R. P. (2004). Vitamin $\mathrm{D}_{2}$ is much less effective than vitamin $\mathrm{D}_{3}$ in humans. J. Clin. Endocrinol. Metab. 89, 5387-5391. doi: 10.1210/jc.2004-0360

Baeke, F., Takiishi, T., Korf, H., Gysemans, C., and Mathieu, C. (2010). Vitamin D: modulator of the immune system. Curr. Opin. Pharmacol. 10, 482-496. doi: 10.1016/j.coph.2010.04.001

Berridge, M. J. (2012). Calcium signalling remodelling and disease. Biochem. Soc. Trans. 40, 297-309. doi: 10.1042/BST20110766

Berry, D. J., Hesketh, K., Power, C., and Hyppönen, E. (2011). Vitamin D status has a linear association with seasonal infections and lung function in British adults. Br. J. Nutr. 106, 1433-1440. doi: 10.1017/S0007114511001991

Biesalski, H. K. (2013). "Hidden hunger in the developed world," in The Road to Good Nutrition, A Global Perspective, 1st Edn., eds M. Eggersdorfer, K. Kraemer,
M. Ruel, M. Van Ameringen, H. K. Biesalski, M. Bloem, et al. (Basel: Karger), $39-50$.

Bilodeau, L., Dufresne, G., Deeks, J., Clément, G., Bertrand, J., Turcotte, S., et al. (2011). Determination of vitamin $\mathrm{D}_{3}$ and 25-hydroxyvitamin $\mathrm{D}_{3}$ in foodstuffs by HPLC UV-DAD and LC-MS/MS. J. Food Compos. Anal. 24, 441-448. doi: 10.1016/j.jfca.2010.08.002

Bischoff, H. A., Stahelin, H. B., Dick, W., Akos, R., Knecht, M., Salis, C., et al. (2003). Effects of vitamin D and calcium supplementation on falls: a randomized controlled trial. J. Bone Miner. Res. 18, 343-351. doi: 10.1359/jbmr.2003.18.2.343

Bischoff-Ferrari, H. A., Dawson-Hughes, B., Staehelin, H. B., Orav, J. E., Stuck, A. E., Theiler, R., et al. (2009). Fall prevention with supplemental and active forms of vitamin D: a meta-analysis of randomised controlled trials. BMJ 339:b3692. doi: 10.1136/bmj.b3692

Bischoff-Ferrari, H. A., Dawson-Hughes, B., Stocklin, E., Sidelnikov, E., Willett, W. C., Edel, J. O., et al. (2012). Oral supplementation with $25(\mathrm{OH}) \mathrm{D}_{3}$ versus vitamin $\mathrm{D}_{3}$ : effects on $25(\mathrm{OH}) \mathrm{D}$ levels, lower extremity function, blood pressure, and markers of innate immunity. J. Bone Miner. Res. 27, 160-169. doi: $10.1002 / j b m r .551$

Bischoff-Ferrari, H. A., Dietrich, T., Orav, E. J., Hu, F. B., Zhang, Y., Karlson, E. W., et al. (2004). Higher 25-hydroxyvitamin D concentrations are associated with better lower-extremity function in both active and inactive persons aged $\geq 60 \mathrm{y}$. Am. J. Clin. Nutr. 80, 752-758.

Boland, R., Skliar, M., Curino, A., and Milanesi, L. (2003). Vitamin D compounds in plants. Plant Sci. 164, 357-369. doi: 10.1016/S0168-9452(02)00420-X

Boland, R. L. (1986). Plants as a source of vitamin $\mathrm{D}_{3}$ metabolites. Nutr. Rev. 44, 1-8. doi: 10.1111/j.1753-4887.1986.tb07543.x

Bossé, Y., Maghni, K., and Hudson, T. J. (2007). 1 $\alpha$,25-dihydroxy-vitamin $\mathrm{D}_{3}$ stimulation of bronchial smooth muscle cells induces autocrine, contractility, and remodeling processes. Physiol. Genomics 29, 161-168. doi: 10.1152/physiolgenomics.00134.2006

Bouillon, R., Carmeliet, G., Lieben, L., Watanabe, M., Perino, A., Auwerx, J., et al. (2014). Vitamin D and energy homeostasis-Of mice and men. Nat. Rev. Endocrinol. 10, 79-87. doi: 10.1038/nrendo.2013.226

Bouillon, R., Lieben, L., Mathieu, C., Verstuyf, A., and Carmeliet, G. (2013). Vitamin D action: lessons from VDR and Cyp27b1 null mice. Pediatr. Endocrinol. Rev. 10(Suppl. 2), 354-366.

Bouillon, R., Okamura, W. H., and Norman, A. W. (1995). Structure-function relationships in the vitamin D endocrine system. Endocr. Rev. 16, 200-257.

Bouillon, R., and Suda, T. (2014). Vitamin D: calcium and bone homeostasis during evolution. Bonekey Rep. 3:480. doi: 10.1038/bonekey.2013.214

Broe, K. E., Chen, T. C., Weinberg, J., Bischoff-Ferrari, H. A., Holick, M. F., and Kiel, D. P. (2007). A higher dose of vitamin D reduces the risk of falls in nursing home residents: a randomized, multiple-dose study. J. Am. Geriatr. Soc. 55, 234-239. doi: 10.1111/j.1532-5415.2007.01048.x

Buell, J. S., and Dawson-Hughes, B. (2008). Vitamin D and neurocognitive dysfunction: preventing "D"ecline? Mol. Aspects Med. 29, 415-422. doi: 10.1016/j.mam.2008.05.001

Burrell, A. M., Handel, A. E., Ramagopalan, S. V., Ebers, G. C., and Morahan, J. M. (2011). Epigenetic mechanisms in multiple sclerosis and the major histocompatibility complex (MHC). Discov. Med. 11, 187-196.

Byrdwell, W. C., Horst, R. L., Phillips, K. M., Holden, J. M., Patterson, K. Y., Harnly, J. M., et al. (2013). Vitamin D levels in fish and shellfish determined by liquid chromatography with ultraviolet detection and mass spectrometry. J. Food Compos. Anal. 30, 109-119. doi: 10.1016/j.jfca.2013. 01.005

Calvo, M. S., Whiting, S. J., and Barton, C. N. (2004). Vitamin D fortification in the United States and Canada: current status and data needs. Am. J. Clin. Nutr. 80, 1710S-1716S.

Cantorna, M. T. (2012). Vitamin D, multiple sclerosis and inflammatory bowel disease. Arch. Biochem. Biophys. 523, 103-106. doi: 10.1016/j.abb.2011. 11.001

Carlberg, C., and Campbell, M. J. (2013). Vitamin D receptor signaling mechanisms: integrated actions of a well-defined transcription factor. Steroids 78, 127-136. doi: 10.1016/j.steroids.2012.10.019

Carlberg, C., Seuter, S., De Mello, V. D., Schwab, U., Voutilainen, S., Pulkki, K., et al. (2013). Primary vitamin d target genes allow a categorization of possible benefits of vitamin $\mathrm{D}_{3}$ supplementation. PLOS ONE 8:e71042. doi: 10.1371/journal.pone.0071042 
Carlberg, C., Seuter, S., and Heikkinen, S. (2012). The first genome-wide view of vitamin D receptor locations and their mechanistic implications. Anticancer Res. 32, 271-282.

Cashman, K. D. (2014). The vitamin D RDA for African American adults: higher than that for white persons? Am. J. Clin. Nutr. 99, 427-428. doi: 10.3945/ajcn.113.082271

Ceglia, L., Niramitmahapanya, S., Da Silva Morais, M., Rivas, D. A., Harris, S. S., Bischoff-Ferrari, H., et al. (2013). A randomized study on the effect of vitamin $\mathrm{D}_{3}$ supplementation on skeletal muscle morphology and vitamin d receptor concentration in older women. J. Clin. Endocrinol. Metab. 98, E1927-E1935. doi: 10.1210/jc.2013-2820

Centers for Disease Control and Prevention \& National Center for Health Statistics. (2009). NHANES 2003-2004, NHANES 2005-2006, NHANES 20072008. Data, Documentation, Codebooks, SAS Code. Dietary Interview. Individual Foods, Total Nutrient Intakes First and Second Day. Hyattsville, MD: U.S. Department of Health and Human Services \& Centers for Disease Control and Prevention. Available online at: http://www.cdc.gov/nchs/nhanes/ nhanes_questionnaires.htm

Charan, J., Goyal, J. P., Saxena, D., and Yadav, P. (2012). Vitamin D for prevention of respiratory tract infections: a systematic review and meta-analysis. J. Pharmacol. Pharmacother. 3, 300-303. doi: 10.4103/0976-500X.103685

Cheng, T. Y., Lacroix, A. Z., Beresford, S. A., Goodman, G. E., Thornquist, M. D., Zheng, Y., et al. (2013). Vitamin D intake and lung cancer risk in the Women's Health Initiative. Am. J. Clin. Nutr. 98, 1002-1011. doi: 10.3945/ajcn.112.055905

Choi, C. J., Seo, M., Choi, W. S., Kim, K. S., Youn, S. A., Lindsey, T., et al. (2013). Relationship between serum 25-hydroxyvitamin D and lung function among Korean adults in Korea National Health and Nutrition Examination Survey, 2008-2010. J. Clin. Endocrinol. Metab. 98, 1703-1710. doi: 10.1210/jc.2012-3901

Collins, E. D., and Norman, A. W. (2001). "Vitamin D," in Handbook of Vitamins, eds R. B. Rucker, J. W. Suttie, D. B. Mccormick, and L. J. Machlin (New York, NY: Marcel Dekker Inc.), 51-113.

Coussens, A. K., Wilkinson, R. J., Hanifa, Y., Nikolayevskyy, V., Elkington, P. T., Islam, K., et al. (2012). Vitamin D accelerates resolution of inflammatory responses during tuberculosis treatment. Proc. Natl. Acad. Sci. U.S.A. 109, 15449-15454. doi: 10.1073/pnas.1200072109

Dastani, Z., Li, R., and Richards, B. (2013). Genetic regulation of vitamin D levels. Calcif. Tissue Int. 92, 106-117. doi: 10.1007/s00223-012-9660-z

De Boer, I. H., Sachs, M. C., Cleary, P. A., Hoofnagle, A. N., Lachin, J. M., Molitch, M. E., et al. (2012). Circulating Vitamin D metabolites and kidney disease in type 1 diabetes. J. Clin. Endocrinol. Metab. 97, 4780-4788. doi: 10.1210/jc.20122852

Dobson, R., Giovannoni, G., and Ramagopalan, S. (2013). The month of birth effect in multiple sclerosis: systematic review, meta-analysis and effect of latitude. J. Neurol. Neurosurg. Psychiatry 84, 427-432. doi: 10.1136/jnnp-2012303934

Dong, J. Y., Zhang, W. G., Chen, J. J., Zhang, Z. L., Han, S. F., and Qin, L. Q. (2013). Vitamin D intake and risk of type 1 diabetes: a meta-analysis of observational studies. Nutrients 5, 3551-3562. doi: 10.3390/nu5093551

Egaas, E., and Lambertsen, G. (1979). Naturally occurring vitamin $\mathrm{D}_{3}$ in fish products analysed by HPLC, using vitamin D2 as an international standard. Int. J. Vitam. Nutr. Res. 49, 35-42.

Exler, J., Phillips, K. M., Patterson, K. Y., and Holden, J. M. (2013). Cholesterol and vitamin D content of eggs in the U.S. retail market. J. Food Compos. Anal. 29, 110-116. doi: 10.1016/j.jfca.2012.11.001

Eyles, D. W., Burne, T. H. J., and McGrath, J. J. (2013). Vitamin D, effects on brain development, adult brain function and the links between low levels of vitamin D and neuropsychiatric disease. Front. Neuroendocrinol. 34, 47-64. doi: 10.1016/j.yfrne.2012.07.001

Flicker, L., Macinnis, R. J., Stein, M. S., Scherer, S. C., Mead, K. E., Nowson, C. A., et al. (2005). Should older people in residential care receive vitamin D to prevent falls? Results of a randomized trial. J. Am. Geriatr. Soc. 53, 1881-1888. doi: 10.1111/j.1532-5415.2005.00468.x

Food and Drug Administration. (2008). Food labeling: health claims; calcium and osteoporosis, and calcium, vitamin D, and osteoporosis. Fed. Regist. 73, 56477-56487.

Forman, J. P., Giovannucci, E., Holmes, M. D., Bischoff-Ferrari, H. A., Tworoger, S. S., Willett, W. C., et al. (2007). Plasma 25-hydroxyvitamin D levels and risk of incident hypertension. Hypertension 49, 1063-1069. doi: 10.1161/HYPERTENSIONAHA.107.087288
Gardner, D. G., Chen, S., Glenn, D. J., and Ni, W. (2011). Vitamin D and The Cardiovascular System. Amsterdam: Elsevier Inc.

German Nutrition Society. (2012). New reference values for vitamin D. Ann. Nutr. Metab. 60, 241-246. doi: 10.1159/000337547

Giovannucci, E., Liu, Y., Hollis, B. W., and Rimm, E. B. (2008). 25-hydroxyvitamin $\mathrm{d}$ and risk of myocardial infarction in men: a prospective study. Arch. Intern. Med. 168, 1174-1180. doi: 10.1001/archinte.168.11.1174

Glendenning, P., Chew, G. T., Seymour, H. M., Gillett, M. J., Goldswain, P. R., Inderjeeth, C. A., et al. (2009). Serum 25-hydroxyvitamin D levels in vitamin D-insufficient hip fracture patients after supplementation with ergocalciferol and cholecalciferol. Bone 45, 870-875. doi: 10.1016/j.bone.2009. 07.015

González-Molero, I., Rojo-Martínez, G., Morcillo, S., Gutiérrez-Repiso, C., Rubio-Martín, E., Almaraz, M. C., et al. (2012). Vitamin D and incidence of diabetes: a prospective cohort study. Clin. Nutr. 31, 571-573. doi: 10.1016/j.clnu.2011.12.001

Grant, W. B., Cross, H. S., Garland, C. F., Gorham, E. D., Moan, J., Peterlik, M., et al. (2009). Estimated benefit of increased vitamin D status in reducing the economic burden of disease in western Europe. Prog. Biophys. Mol. Biol. 99, 104-113. doi: 10.1016/j.pbiomolbio.2009.02.003

Haslberger, A., Varga, F., and Karlic, H. (2006). Recursive causality in evolution: a model for epigenetic mechanisms in cancer development. Med. Hypotheses 67, 1448-1454. doi: 10.1016/j.mehy.2006.05.047

Haytowitz, D. B., Lemar, L. E., and Pehrsson, P. R. (2009). USDA's Nutrient Databank System -a tool for handling data from diverse sources. J. Food Compos. Anal. 22, 433-441. doi: 10.1016/j.jfca.2009.01.003

Health Canada. (2014). Consolidation Food and Drugs Regulation. Ottawa, ON: The Minister of Justice Canada.

Heaney, R. P., Recker, R. R., Grote, J., Horst, R. L., and Armas, L. A. (2011). Vitamin $\mathrm{D}_{3}$ is more potent than vitamin $\mathrm{D}_{2}$ in humans. J. Clin. Endocrinol. Metab. 96, E447-E452. doi: 10.1210/jc.2010-2230

Heikkinen, S., Vaisanen, S., Pehkonen, P., Seuter, S., Benes, V., and Carlberg, C. (2011). Nuclear hormone lalpha,25-dihydroxyvitamin $\mathrm{D}_{3}$ elicits a genomewide shift in the locations of VDR chromatin occupancy. Nucleic Acids Res. 39, 9181-9193. doi: 10.1093/nar/gkr654

Henderson, L., Irving, K., Gregory, J. F., Bates, C. J., Prentice, A., Perks, J., et al. (2003). The National Diet and Nutrition Survey: Adults Aged 19-64 Years. Vol. 3: Vitamin and Mineral Intake and Urinary Analytes. London: The Stationery Office.

Hess, A. F., and Weinstock, M. (1925a). The antirachitic value of irradiated cholesterol an phytosterol. II. Further evidence of change in biological activity. Methods Enzymol. 64, 181-191.

Hess, A. F., and Weinstock, M. (1925b). The antirachitic value of irradiated cholesterol an phytosterol. III. Evidence of chemical change as shown by absorption spectra. Methods Enzymol. 64, 193-201.

Hewison, M. (2012). An update on vitamin D and human immunity. Clin. Endocrinol. 76, 315-325. doi: 10.1111/j.1365-2265.2011.04261.x

Hilger, J., Friedel, A., Herr, R., Rausch, T., Roos, F., Wahl, D. A., et al. (2014). A systematic review of vitamin D status in populations worldwide. Br. J. Nutr. 111, 23-45. doi: 10.1017/S0007114513001840

Hirani, V. (2013). Associations between vitamin D and self-reported respiratory disease in older people from a nationally representative population survey. J. Am. Geriatr. Soc. 61, 969-973. doi: 10.1111/jgs.12254

Holick, M. F. (2003). Vitamin D: a millenium perspective. J. Cell. Biochem. 88, 296-307. doi: 10.1002/jcb.10338

Holick, M. F. (2007). Vitamin D deficiency. N. Engl J. Med 357, 266-281. doi: 10.1056/NEJMra070553

Holick, M. F. (2011). “Photobiology of Vitamin D,” in Vitamin D, 3rd Edn., eds D. Feldman, J. W. Pike, and J. S. Adams (London, GB: Elsevier), 13-22.

Holick, M. F., Biancuzzo, R. M., Chen, T. C., Klein, E. K., Young, A., Bibuld, D., et al. (2008). Vitamin $\mathrm{D}_{2}$ is as effective as vitamin $\mathrm{D}_{3}$ in maintaining circulating concentrations of 25-hydroxyvitamin D. J. Clin. Endocrinol. Metab. 93, 677-681. doi: 10.1210/jc.2007-2308

Holick, M. F., Binkley, N. C., Bischoff-Ferrari, H. A., Gordon, C. M., Hanley, D. A., Heaney, R. P., et al. (2011). Evaluation, treatment, and prevention of vitamin d deficiency: an endocrine society clinical practice guideline. J. Clin. Endocrinol. Metab. 96, 1911-1930. doi: 10.1210/jc.2011-0385

Holick, M. F., and Chen, T. C. (2008). Vitamin D deficiency: a worldwide problem with health consequences. Am. J. Clin. Nutr. 87, 1080S-1086S. 
Holick, M. F., Matsuoka, L. Y., and Wortsman, J. (1989). Age, vitamin D, and solar ultraviolet. Lancet 2, 1104-1105. doi: 10.1016/S0140-6736(89)91124-0

Hossein-Nezhad, A., and Holick, M. F. (2012). Optimize dietary intake of vitamin D: an epigenetic perspective. Curr. Opin. Clin. Nutr. Metab. Care 15, 567-579. doi: 10.1097/MCO.0b013e3283594978

Hossein-Nezhad, A., Spira, A., and Holick, M. F. (2013). Influence of vitamin D status and vitamin $\mathrm{D}_{3}$ supplementation on genome wide expression of white blood cells: a randomized double-blind clinical trial. PLOS ONE 8:e58725. doi: 10.1371/journal.pone.0058725

Houston, D. K., Tooze, J. A., Hausman, D. B., Johnson, M. A., Nicklas, B. J., Miller, M. E., et al. (2011). Change in 25-hydroxyvitamin D and physical performance in older adults. J. Gerontol. A Biol. Sci. Med. Sci. 66, 430-436. doi: 10.1093/gerona/glq235

Huaman, M. A., Sterling, T. R., Shepherd, B. E., and Fiske, C. T. (2014). 25Hydroxyvitamin D levels after recovery from tuberculosis: insights into pathogenesis. Tuberculosis (Edinb) 94, 51-54. doi: 10.1016/j.tube.2013.10.009

Huldschinsky, K. (1919). Heilung von Rachitis durch künstliche Höhensonne. Dtsch. Med. Wochenschr. 45, 712-713. doi: 10.1055/s-0028-1137830

Huldschinsky, K. (1926). The antirachitic: zone of the ultra-violet. Klinische Wochenschrift 5, 1972-1973. doi: 10.1007/BF01710213

Hypponen, E., Laara, E., Reunanen, A., Jarvelin, M. R., and Virtanen, S. M. (2001). Intake of vitamin D and risk of type 1 diabetes: a birth-cohort study. Lancet 358, 1500-1503. doi: 10.1016/S0140-6736(01)06580-1

Institute of Medicine, F. A. N. B. (2011). Dietary Reference Intakes for Calcium and Vitamin D. Washington, DC: The National Academies Press.

Jakobsen, J., and Knuthsen, P. (2014). Stability of vitamin D in foodstuffs during cooking. Food Chem. 148, 170-175. doi: 10.1016/j.foodchem.2013.10.043

Jakobsen, J., and Saxholt, E. (2009). Vitamin D metabolites in bovine milk and butter. J. Food Compos. Anal. 22, 472-478. doi: 10.1016/j.jfca.2009. 01.010

Japelt, R. B., Silvestro, D., Smedsgaard, J., Jensen, P. E., and Jakobsen, J. (2013). Quantification of vitamin $\mathrm{D}_{3}$ and its hydroxylated metabolites in waxy leaf nightshade (Solanum glaucophyllum Desf.), tomato (Solanum lycopersicum L.) and bell pepper (Capsicum annuum L.). Food Chem. 138, 1206-1211. doi: 10.1016/j.foodchem.2012.11.064

Karakas, M., Thorand, B., Zierer, A., Huth, C., Meisinger, C., Roden, M., et al. (2013). Low levels of serum 25-hydroxyvitamin d are associated with increased risk of myocardial infarction, especially in women: results from the MONICA/KORA augsburg case-cohort study. J. Clin. Endocrinol. Metab. 98, 272-280. doi: 10.1210/jc.2012-2368

Karlic, H., and Varga, F. (2011). Impact of vitamin D metabolism on clinical epigenetics. Clin. Epigenetics 2, 55-61. doi: 10.1007/s13148-011-0021-y

Khan, H., Kunutsor, S., Franco, O. H., and Chowdhury, R. (2013). Vitamin D, type 2 diabetes and other metabolic outcomes: a systematic review and meta-analysis of prospective studies. Proc. Nutr. Soc. 72, 89-97. doi: $10.1017 /$ S0029665112002765

Kobayashi, T., Takeuchi, A., and Okano, T. (1995). "Vitamin D contents in various kinds of Japanese foods," in Challenges of Modern Medicine (Rome: Ares-Serono Symposia), 345-350.

Lee, V., Rekhi, E., Hoh Kam, J., and Jeffery, G. (2012). Vitamin D rejuvenates aging eyes by reducing inflammation, clearing amyloid beta and improving visual function. Neurobiol. Aging 33, 2382-2389. doi: 10.1016/j.neurobiolaging.2011.12.002

Lehmann, B., Genehr, T., Knuschke, P., Pietzsch, J., and Meurer, M. (2001). UVBinduced conversion of 7-dehydrocholesterol to lalpha,25-dihydroxyvitamin $\mathrm{D}_{3}$ in an in vitro human skin equivalent model. J. Invest. Dermatol. 117, 1179-1185. doi: 10.1046/j.0022-202x.2001.01538.x

Lehmann, U., Hirche, F., Stangl, G. I., Hinz, K., Westphal, S., and Dierkes, J. (2013). Bioavailability of vitamin $\mathrm{D}_{2}$ and $\mathrm{D}_{3}$ in healthy volunteers, a randomized placebo-controlled trial. J. Clin. Endocrinol. Metab. 98, 4339-4345. doi: 10.1210/jc.2012-4287

Lips, P. (2001). Vitamin D deficiency and secondary hyperparathyroidism in the elderly: consequences for bone loss and fractures and therapeutic implications. Endocr. Rev. 22, 477-501. doi: 10.1210/edrv.22.4.0437

Lips, P. (2007). Relative value of $25(\mathrm{OH}) \mathrm{D}$ and $1,25(\mathrm{OH}) 2 \mathrm{D}$ measurements. J. Bone Miner. Res. 22, 1668-1671. doi: 10.1359/jbmr.070716

Lips, P. (2010). Worldwide status of vitamin D nutrition. J. Steroid Biochem. Mol. Biol. 121, 297-300. doi: 10.1016/j.jsbmb.2010.02.021
Lips, P., and Van Schoor, N. (2011). "Worldwide vitamin D status," in Vitamin D, $3 r d$ Edn., eds D. Feldman, J. W. Pike, and J. S. Adams (London, GB: Elsevier Inc.), 947-963.

Lips, P., Van Schoor, N. M., and Bravenboer, N. (2013). "Vitamin D-related disorders," in Primer on the Metabolic Bone Diseases and Disorders of Mineral Metabolism 8th Edn., eds R. B. Clifford J. Rosen, J. E. Compston, V. Rosen (Singapore: John Wiley \& Sons, Inc.), 613-623.

Looker, A. C., Dawson-Hughes, B., Calvo, M. S., Gunter, E. W., and Sahyoun, N. R. (2002). Serum 25-hydroxyvitamin D status of adolescents and adults in two seasonal subpopulations from NHANES III. Bone 30, 771-777. doi: 10.1016/S8756-3282(02)00692-0

Lu, Z., Chen, T. C., Zhang, A., Persons, K. S., Kohn, N., Berkowitz, R., et al. (2007). An evaluation of the vitamin $\mathrm{D}_{3}$ content in fish: is the vitamin $\mathrm{D}$ content adequate to satisfy the dietary requirement for vitamin D? J. Steroid Biochem. Mol. Biol. 103, 642-644. doi: 10.1016/j.jsbmb.2006.12.010

MacLaughlin, J., and Holick, M. F. (1985). Aging decreases the capacity of human skin to produce vitamin $\mathrm{D}_{3}$. J. Clin. Invest. 76, 1536-1538. doi: 10.1172/JCI112134

Martineau, A. R., Timms, P. M., Bothamley, G. H., Hanifa, Y., Islam, K., Claxton, A. P., et al. (2011). High-dose vitamin $\mathrm{D}_{3}$ during intensive-phase antimicrobial treatment of pulmonary tuberculosis: a double-blind randomised controlled trial. Lancet 377, 242-250. doi: 10.1016/S0140-6736(10)61889-2

Matsuoka, L. Y., Wortsman, J., Haddad, J. G., Kolm, P., and Hollis, B. W. (1991). Racial pigmentation and the cutaneous synthesis of vitamin D. Arch. Dermatol. 127, 536-538. doi: 10.1001/archderm.1991.04510010104011

Mattila, P., Konko, K., Eurola, M., Pihlava, J. M., Astola, J., Vahteristo, L., et al. (2001). Contents of vitamins, mineral elements, and some phenolic compounds in cultivated mushrooms. J. Agric. Food Chem. 49, 2343-2348. doi: 10.1021/jf001525d

Mattila, P., Lehikoinen, K., Kiiskinen, T., and Piironen, V. (1999a). Cholecalciferol and 25-hydroxycholecalciferol content of chicken egg yolk as affected by the cholecalciferol content of feed. J. Agric. Food Chem. 47, 4089-4092. doi: 10.1021/jf990183c

Mattila, P., Piironen, V., Bäckman, C., Asunmaa, A., Uusi-Rauva, E., and Koivistoinen, P. (1992). Determination of vitamin $\mathrm{D}_{3}$ in egg yolk by highperformance liquid chromatography with diode array detection. J. Food Compost. Anal. 5, 281-290. doi: 10.1016/0889-1575(92)90062-O

Mattila, P., Piironen, V., Haapala, R., Hirvi, T., and Uusi-Rauva, E. (1997). Possible factors responsible for the high variation in the cholecalciferol contents of fish. J. Agric. Food Chem. 45, 3891-3896. doi: 10.1021/jf970243j

Mattila, P., Piironen, V., Uusi-Rauva, E., and Koivistoinen, P. (1995a). Cholecalciferol and 25-hydroxycholecalciferol contents in fish and fish products. J. Food Compost. Anal. 8, 232-243. doi: 10.1006/jfca.1995.1017

Mattila, P., Ronkainen, R., Lehikoinen, K., and Piironen, V. (1999b). Effect of Household Cooking on the Vitamin D content in Fish, Eggs, and Wild Mushrooms. J. Food Compost. Anal. 12, 153-160. doi: 10.1006/jfca. 1999.0828

Mattila, P. H., Piironen, V. I., Uusi-Rauva, E. J., and Koivistoinen, P. E. (1994). Vitamin D contents in edible mushrooms. J. Agric. Food Chem. 42, 2449-2453. doi: 10.1021/jf00047a016

Mattila, P. H., Piironen, V. I., Uusi-Rauva, E. J., and Koivistoinen, P. E. (1995b). Contents of cholecalciferol, ergocalciferol, and their 25-hydroxylated metabolites in milk products and raw meat and liver as determined by HPLC. J. Agric. Food Chem. 43, 2394-2399. doi: 10.1021/jf00057a015

Mau, J. L., Chen, P. R., and Yang, J. H. (1998). Ultraviolet irradiation increased vitamin $\mathrm{D}_{2}$ content in edible mushrooms. J. Agric. Food Chem. 46, 5269-5272. doi: $10.1021 /$ jf980602q

Max Rubner-Institut. (2008). Nationale Verzehrsstudie II. Ergebnisbericht Teil 2. Die bundesweite Befragung zur Ernaehrung von Jugendlichen und Erwachsenen (National Food Intake Study II. Results Part 2. Countrywide Assessment of Nutrition in Adolescents and Adults). Karlsruhe: Max Rubner-Institut Available online at: http://www.was-esse-ich.de/uploads/media/NVSII Abschlussbericht_Teil_2.pdf

McCann, J. C., and Ames, B. N. (2009). Vitamin K, an example of triage theory: is micronutrient inadequacy linked to diseases of aging? Am. J. Clin. Nutr. 90, 889-907. doi: 10.3945/ajcn.2009.27930

Mellanby, E. (1919). An experimental investigation on rickets. Lancet 193, 407-412. doi: 10.1016/S0140-6736(01)25465-8 
Mellanby, E. (1976). Nutrition classics. the lancet 1:407-12, 1919. An experimental investigation on rickets. Nutr. Rev. 34, 338-340. doi: 10.1111/j.17534887.1976.tb05815.x

Millen, A. E., Voland, R., Sondel, S. A., Parekh, N., Horst, R. L., Wallace, R. B., et al. (2011). Vitamin D status and early age-related macular degeneration in postmenopausal women. Arch. Ophthalmol. 129, 481-489. doi: 10.1001/archophthalmol.2011.48

Mitchell, K., Griffiths, C. J., and Martineau, A. R. (2011). Vitamin D and tuberculosis. Curr. Respir. Med. Rev. 7, 435-439. doi: 10.2174/157339811798072685

Mithal, A., Wahl, D. A., Bonjour, J. P., Burckhardt, P., Dawson-Hughes, B., Eisman, J. A., et al. (2009). Global vitamin D status and determinants of hypovitaminosis D. Osteoporos Int. 20, 1807-1820. doi: 10.1007/s00198-009-0954-6

Montgomery, J. L., Carr, M. A., Kerth, C. R., Hilton, G. G., Price, B. P., Galyean, M. L., et al. (2002). Effect of vitamin $\mathrm{D}_{3}$ supplementation level on the postmortem tenderization of beef from steers. J. Anim. Sci. 80, 971-981.

Montgomery, J. L., King, M. B., Gentry, J. G., Barham, A. R., Barham, B. L., Hilton, G. G., et al. (2004). Supplemental vitamin $\mathrm{D}_{3}$ concentration and biological type of steers. II. Tenderness, quality, and residues of beef. J. Anim. Sci. 82, 2092-2104.

Montgomery, J. L., Parrish, F. C., Beitz, D. C., Horst, R. L., Huff-Lonergan, E. J., and Trenkle, A. H. (2000). The use of vitamin $\mathrm{D}_{3}$ to improve beef tenderness. J. Anim. Sci. 78, 2615-2621.

Nesby-O'dell, S., Scanlon, K. S., Cogswell, M. E., Gillespie, C., Hollis, B. W., Looker, A. C., et al. (2002). Hypovitaminosis D prevalence and determinants among African American and white women of reproductive age: third National Health and Nutrition Examination Survey, 1988-1994. Am. J. Clin. Nutr. 76, 187-192.

Ng, K., Meyerhardt, J. A., Wu, K., Feskanich, D., Hollis, B. W., Giovannucci, E. L., et al. (2008). Circulating 25-hydroxyvitamin d levels and survival in patients with colorectal cancer. J. Clin. Oncol. 26, 2984-2991. doi: 10.1200/JCO.2007.15.1027

Ng, K., Scott, J. B., Drake, B. F., Chan, A. T., Hollis, B. W., Chandler, P. D., et al. (2014). Dose response to vitamin D supplementation in African Americans: results of a 4-arm, randomized, placebo-controlled trial. Am. J. Clin. Nutr. 99, 587-598. doi: 10.3945/ajcn.113.067777

Nnoaham, K. E., and Clarke, A. (2008). Low serum vitamin D levels and tuberculosis: a systematic review and meta-analysis. Int. J. Epidemiol. 37, 113-119. doi: 10.1093/ije/dym 247

Norman, A. W. (2012). The history of the discovery of vitamin D and its daughter steroid hormone. Ann. Nutr. Metab. 61, 199-206. doi: 10.1159/000343104

Norman, A. W., Ishizuka, S., and Okamura, W. H. (2001). Ligands for the vitamin $\mathrm{D}$ endocrine system: different shapes function as agonists and antagonists for genomic and rapid response receptors or as a ligand for the plasma vitamin D binding protein. J. Steroid. Biochem. Mol. Biol. 76, 49-59. doi: 10.1016/S09600760(00)00145-X

Norman, A. W., Okamura, W. H., Bishop, J. E., and Henry, H. L. (2002). Update on biological actions of 1alpha, $25(\mathrm{OH})_{2}$-vitamin $\mathrm{D}_{3}$ (rapid effects) and 24R,25(OH) $)_{2}$-vitamin $\mathrm{D}_{3}$. Mol. Cell. Endocrinol. 197, 1-13. doi: 10.1016/S03037207(02)00273-3

Ostermeyer, U., and Schmidt, T. (2006). Vitamin D and provitamin D in fish: determination by HPLC with electrochemical detection. Eur. Food Res. Technol. 222, 403-413. doi: 10.1007/s00217-005-0086-y

Ovesen, L., Brot, C., and Jakobsen, J. (2003). Food contents and biological activity of 25-hydroxyvitamin D: a vitamin D metabolite to be reckoned with? Ann. Nutr. Metab. 47, 107-113. doi: 10.1159/000070031

Parekh, N., Chappell, R. J., Millen, A. E., Albert, D. M., and Mares, J. A. (2007). Association between Vitamin D and age-related macular degeneration in the third National Health and Nutrition Examination Survey, 1988 through 1994. Arch. Ophthalmol. 125, 661-669. doi: 10.1001/archopht.125. 5.661

Parrish, D. B. (1979). Determination of vitamin D in foods: a review. CRC Crit. Rev. Food Sci. Nutr. 12, 29-57. doi: 10.1080/10408397909527272

Perrine, C. G., Sharma, A. J., Jefferds, M. E. D., Serdula, M. K., and Scanlon, K. S. (2010). Adherence to vitamin D recommendations among US infants. Pediatrics 125, 627-632. doi: 10.1542/peds.2009-2571

Pfeifer, M., Begerow, B., Minne, H. W., Abrams, C., Nachtigall, D., and Hansen, C. (2000). Effects of a short-term vitamin D and calcium supplementation on body sway and secondary hyperparathyroidism in elderly women. J. Bone Miner. Res. 15, 1113-1118. doi: 10.1359/jbmr.2000.15.6.1113
Pfeifer, M., Begerow, B., Minne, H. W., Suppan, K., Fahrleitner-Pammer, A., and Dobnig, H. (2009). Effects of a long-term vitamin D and calcium supplementation on falls and parameters of muscle function in community-dwelling older individuals. Osteoporos. Int. 20, 315-322. doi: 10.1007/s00198-008-0662-7

Phillips, K. M., Ruggio, D. M., Horst, R. L., Minor, B., Simon, R. R., Feeney, M. J., et al. (2011). Vitamin D and sterol composition of 10 types of mushrooms from retail suppliers in the United States. J. Agric. Food Chem. 59, 7841-7853. doi: 10.1021/jf104246z

Pike, J. W., Lee, S. M., and Meyer, M. B. (2014). Regulation of gene expression by 1,25-dihydroxyvitamin D in bone cells: exploiting new approaches and defining new mechanisms. Bonekey Rep. 3, 482. doi: 10.1038/bonekey.2013.216

Pilz, S., Gaksch, M., O’Hartaigh, B., Tomaschitz, A., and März, W. (2013a). The role of vitamin D deficiency in cardiovascular disease: where do we stand in 2013 ? Arch. Toxicol. 87, 2083-2103. doi: 10.1007/s00204-013-1152-z

Pilz, S., Kienreich, K., Rutters, F., De Jongh, R., Van Ballegooijen, A. J., Grubler, M., et al. (2013b). Role of vitamin D in the development of insulin resistance and type 2 diabetes. Curr. Diab. Rep. 13, 261-270. doi: 10.1007/s11892-012-0358-4

Pittas, A. G., Lau, J., Hu, F. B., and Dawson-Hughes, B. (2007). The role of vitamin $\mathrm{D}$ and calcium in type 2 diabetes. A systematic review and meta-analysis. J. Clin. Endocrinol. Metab. 92, 2017-2029. doi: 10.1210/jc.2007-0298

Platt, B. S. (1956). Sir Edward Mellanby, 8 April 1884-30 January 1955. Br. J. Nutr. 10, 177-181.

Prentice, A. (2008). Vitamin D deficiency: a global perspective. Nutr. Rev. 66, S153-S164. doi: 10.1111/j.1753-4887.2008.00100.x

Prince, R. L., Austin, N., Devine, A., Dick, I. M., Bruce, D., and Zhu, K. (2008). Effects of ergocalciferol added to calcium on the risk of falls in elderly high-risk women. Arch. Int. Med. 168, 103-108. doi: 10.1001/archinternmed.2007.31

Ramagopalan, S. V., Heger, A., Berlanga, A. J., Maugeri, N. J., Lincoln, M. R., Burrell, A., et al. (2010). A ChIP-seq defined genome-wide map of vitamin $\mathrm{D}$ receptor binding: associations with disease and evolution. Genome Res. 20, 1352-1360. doi: 10.1101/gr.107920.110

Ramos-Lopez, E., Jansen, T., Ivaskevicius, V., Kahles, H., Klepzig, C., Oldenburg, J., et al. (2006). Protection from type 1 diabetes by vitamin D receptor haplotypes. Ann. N Y. Acad. Sci. 1079, 327-334. doi: 10.1196/annals.1375.050

Redzic, M., Lewis, R. M., and Thomas, D. T. (2013). Relationship between 25hydoxyvitamin D, muscle strength, and incidence of injury in healthy adults: a systematic review. Nutr. Res. 33, 251-258. doi: 10.1016/j.nutres.2013.02.007

Roberts, J. S., Teichert, A., and McHugh, T. H. (2008). Vitamin D2 formation from post-harvest UV-B treatment of mushrooms (Agaricus bisporus) and retention during storage. J. Agricultur. Food Chem. 56, 4541-4544. doi: 10.1021/jf0732511

Romagnoli, E., Mascia, M. L., Cipriani, C., Fassino, V., Mazzei, F., D’Erasmo, E., et al. (2008). Short and long-term variations in serum calciotropic hormones after a single very large dose of ergocalciferol (vitamin D2) or cholecalciferol (vitamin $\mathrm{D}_{3}$ ) in the elderly. J. Clin. Endocrinol. Metab. 93, 3015-3020. doi: 10.1210/jc.2008-0350

Rosen, C. J., Adams, J. S., Bikle, D. D., Black, D. M., Demay, M. B., Manson, J. E., et al. (2012). The nonskeletal effects of vitamin D: an Endocrine Society scientific statement. Endocr. Rev. 33, 456-492. doi: 10.1210/er.2012-1000

Ross, A. C., Manson, J. E., Abrams, S. A., Aloia, J. F., Brannon, P. M., Clinton, S. K., et al. (2011). The 2011 report on dietary reference intakes for calcium and vitamin d from the institute of medicine: what clinicians need to know. J. Clin. Endocrinol. Metab. 96, 53-58. doi: 10.1210/jc.2010-2704

Salahuddin, N., Ali, F., Hasan, Z., Rao, N., Aqeel, M., and Mahmood, F. (2013). Vitamin D accelerates clinical recovery from tuberculosis: results of the SUCCINCT Study [Supplementary Cholecalciferol in recovery from tuberculosis]. A randomized, placebo-controlled, clinical trial of vitamin D supplementation in patients with pulmonary tuberculosis'. BMC Infect. Dis. 13:22. doi: 10.1186/1471-2334-13-22

Schmid, A., and Walther, B. (2013). Natural vitamin D content in animal products. Adv. Nutr. 4, 453-462. doi: 10.3945/an.113.003780

Schottker, B., Herder, C., Rothenbacher, D., Perna, L., Muller, H., and Brenner, H. (2013). Serum 25-hydroxyvitamin D levels and incident diabetes mellitus type 2: a competing risk analysis in a large population-based cohort of older adults. Eur. J. Epidemiol. 28, 267-275. doi: 10.1007/s10654-013-9769-z

Schroten, N. F., Ruifrok, W. P., Kleijn, L., Dokter, M. M., Sillje, H. H., Lambers Heerspink, H. J., et al. (2013). Short-term vitamin $\mathrm{D}_{3}$ supplementation lowers plasma renin activity in patients with stable chronic heart failure: an open-label, blinded end point, randomized prospective trial (VitD-CHF trial). Am. Heart J. 166, 357-364.e352. doi: 10.1016/j.ahj.2013.05.009 
Schwalfenberg, G. K. (2011). A review of the critical role of vitamin D in the functioning of the immune system and the clinical implications of vitamin D deficiency. Mol. Nutr. Food Res. 55, 96-108. doi: 10.1002/mnfr.201000174

Sohl, E., Van Schoor, N. M., De Jongh, R. T., Visser, M., Deeg, D. J., and Lips, P. (2013). Vitamin d status is associated with functional limitations and functional decline in older individuals. J. Clin. Endocrinol. Metab. 98, E1483-E1490. doi: 10.1210/jc.2013-1698

Solomon, A. J., and Whitham, R. H. (2010). Multiple sclerosis and vitamin D: a review and recommendations. Curr. Neurol. Neurosci. Rep. 10, 389-396. doi: 10.1007/s11910-010-0131-5

Strobel, N., Buddhadasa, S., Adorno, P., Stockham, K., and Greenfield, H. (2013). Vitamin D and 25-hydroxyvitamin D determination in meats by LC-IT-MS. Food Chem. 138, 1042-1047. doi: 10.1016/j.foodchem.2012.08.041

Sundar, I. K., and Rahman, I. (2011). Vitamin D and susceptibility of chronic lung diseases: role of epigenetics. Front. Pharmacol. 2:50. doi: 10.3389/fphar.2011.00050

Takeuchi, A., Okano, T., Ayame, M., Yoshikawa, H., Teraoka, S., Murakami, Y., et al. (1984). High-performance liquid chromatographic determination of vitamin $\mathrm{D}_{3}$ in fish liver oils and eel body oils. J. Nutr. Sci. Vitaminol. 30, 421-430. doi: 10.3177/jnsv.30.421

Takeuchi, A., Okano, T., Sayamoto, M., Sawamura, S., Kobayashi, T., Motosugi, M., et al. (1986). Tissue distribution of 7-dehydrocholesterol, vitamin $\mathrm{D}_{3}$ and 25hydroxyvitamin $\mathrm{D}_{3}$ in several species of fishes. J. Nutr. Sci. Vitaminol. 32, 13-22. doi: $10.3177 /$ jnsv.32.13

Tamez, H., and Thadhani, R. I. (2012). Vitamin D and hypertension: an update and review. Curr. Opin. Nephrol. Hypertens. 21, 492-499. doi: 10.1097/MNH.0b013e3283557bf0

Tarroni, P., Villa, I., Mrak, E., Zolezzi, F., Mattioli, M., Gattuso, C., et al. (2012). Microarray analysis of $1,25(\mathrm{OH})_{2} \mathrm{D}_{3}$ regulated gene expression in human primary osteoblasts. J. Cell. Biochem. 113, 640-649. doi: 10.1002/jcb.23392

Teichmann, A., Dutta, P. C., Staffas, A., and Jägerstad, M. (2007). Sterol and vitamin $\mathrm{D}_{2}$ concentrations in cultivated and wild grown mushrooms: effects of UV irradiation. LWT Food Sci. Technol. 40, 815-822. doi: 10.1016/j.lwt.2006.04.003

Tieland, M., Brouwer-Brolsma, E. M., Nienaber-Rousseau, C., Van Loon, L. J., and De Groot, L. C. (2013). Low vitamin D status is associated with reduced muscle mass and impaired physical performance in frail elderly people. Eur. J. Clin. Nutr. 67, 1050-1055. doi: 10.1038/ejcn.2013.144

Tippetts, M., Martini, S., Brothersen, C., and McMahon, D. J. (2012). Fortification of cheese with vitamin $\mathrm{D}_{3}$ using dairy protein emulsions as delivery systems. J. Dairy Sci. 95, 4768-4774. doi: 10.3168/jds.2011-5134

Trang, H. M., Cole, D. E., Rubin, L. A., Pierratos, A., Siu, S., and Vieth, R. (1998). Evidence that vitamin $\mathrm{D}_{3}$ increases serum 25-hydroxyvitamin D more efficiently than does vitamin $\mathrm{D}_{2}$. Am. J. Clin. Nutr. 68, 854-858.

Trenerry, V. C., Plozza, T., Caridi, D., and Murphy, S. (2011). The determination of vitamin $\mathrm{D}_{3}$ in bovine milk by liquid chromatography mass spectrometry. Food Chem. 125, 1314-1319. doi: 10.1016/j.foodchem.2010.09.097

Troesch, B., Hoeft, B., McBurney, M., Eggersdorfer, M., and Weber, P. (2012). Dietary surveys indicate vitamin intakes below recommendations are common in representative Western countries. Br. J. Nutr. 108, 692-698. doi: $10.1017 /$ S0007114512001808

Tsur, A., Feldman, B. S., Feldhammer, I., Hoshen, M. B., Leibowitz, G., and Balicer, R. D. (2013). Decreased serum concentrations of 25-hydroxycholecalciferol are associated with increased risk of progression to impaired fasting glucose and diabetes. Diabetes Care 36, 1361-1367. doi: 10.2337/dc12-1050
U.S. Department of Agriculture. (2013). USDA National Nutrient Database for Standard Reference, Release 26. Nutrient Data Laboratory Home Page. Available online at: http://www.ars.usda.gov/ba/ bhnrc/ndl (Accessed February 10, 2014).

Van Belle, T. L., Gysemans, C., and Mathieu, C. (2013). Vitamin D and diabetes: the odd couple. Trends Endocrinol. Metab. 24, 561-568. doi: 10.1016/j.tem.2013.07.002

van Rossum, C. T. M., Fransen, H. P., Verkaik-Kloosterman J., Buurma-Rethans, E. J. M., and Ocke, M. C. (2011). Dutch National Food Consumption Survey 20072010: Diet of Children and Adults Aged 7 to 69 Years. Bilthoven: RIVM.

Wacker, M., and Holick, M. (2013). Vitamin D-effects on skeletal and extraskeletal health and the need for supplementation. Nutrients 5, 111-148. doi: 10.3390/nu5010111

Wagner, D., Sidhom, G., Whiting, S. J., Rousseau, D., and Vieth, R. (2008). The bioavailability of vitamin $\mathrm{D}$ from fortified cheeses and supplements is equivalent in adults. J. Nutr. 138, 1365-1371.

Wahl, D. A., Cooper, C., Ebeling, P. R., Eggersdorfer, M., Hilger, J., Hoffmann, K., et al. (2012). A global representation of vitamin D status in healthy populations. Arch. Osteoporos. 7, 155-172. doi: 10.1007/s11657-012-0093-0

Webb, A. R., Kline, L., and Holick, M. F. (1988). Influence of season and latitude on the cutaneous synthesis of vitamin $\mathrm{D}_{3}$ : exposure to winter sunlight in boston and edmonton will not promote vitamin $\mathrm{D}_{3}$ synthesis in human skin. J. Clin. Endocrinol. Metab. 67, 373-378. doi: 10.1210/jcem-672-373

Welsh, J. (2012). Cellular and molecular effects of vitamin D on carcinogenesis. Arch. Biochem. Biophys. 523, 107-114. doi: 10.1016/j.abb.2011.10.019

White, J. H. (2012). Vitamin D metabolism and signaling in the immune system. Rev. Endocr. Metab. Disord. 13, 21-29. doi: 10.1007/s11154-0119195-Z

Windaus, A., Schenck, F., and Von Werder, F. (1936). Über das antirachitisch wirksame Bestrahlungsprodukt aus 7-Dehydrocholesterin. Hoppe-Seyler's Zeitschrift für Physiologische Chemie 241, 100-103. doi: 10.1515/bchm2.1936.241. $1-3.100$

Zadshir, A., Tareen, N., Pan, D., Norris, K., and Martins, D. (2005). The prevalence of hypovitaminosis D among US adults: data from the NHANES III. Ethn. Dis. 15, S5-97-S95-101.

Zhao, Y., Sun, Y., Ji, H. F., and Shen, L. (2013). Vitamin D levels in Alzheimer's and Parkinson's diseases: a meta-analysis. Nutrition 29, 828-832. doi: 10.1016/j.nut.2012.11.018

Conflict of Interest Statement: The authors are employees of DSM Nutritional Products Ltd. and declare to have no conflict of interest.

Received: 24 March 2014; accepted: 14 June 2014; published online: 11 July 2014. Citation: Bendik I, Friedel A, Roos FF, Weber P and Eggersdorfer M (2014) Vitamin D: a critical and essential micronutrient for human health. Front. Physiol. 5:248. doi: $10.3389 /$ fphys.2014.00248

This article was submitted to Integrative Physiology, a section of the journal Frontiers in Physiology.

Copyright (c) 2014 Bendik, Friedel, Roos, Weber and Eggersdorfer. This is an openaccess article distributed under the terms of the Creative Commons Attribution License (CC BY). The use, distribution or reproduction in other forums is permitted, provided the original author(s) or licensor are credited and that the original publication in this journal is cited, in accordance with accepted academic practice. No use, distribution or reproduction is permitted which does not comply with these terms. 